\title{
Coal petrology analysis and implications in depositional environments from upper Cretaceous to Miocene: a study case in the Eastern Cordillera of Colombia
}

\author{
Clara Guatame ${ }^{1}$ (D) Marco Rincón $^{1}$
}

Received: 16 July 2020/Revised: 15 September 2020/Accepted: 18 December 2020/Published online: 6 February 2021

(C) The Author(s) 2021

\begin{abstract}
The Piedemonte Llanero Basin is located on the eastern side of the Eastern Cordillera of the Colombian Andes. It has been the subject of numerous geological studies carried out for the oil sector, mainly. This study presents the coalpetrographical features of 15 coal seams of four geological formations from Late Cretaceous to Middle Miocene (Chipaque formation, Palmichal group, Arcillas del Limbo formation, and San Fernando formation). Analysis of 33 samples indicates enrichment in vitrinite, while liptinite and inertinite concentrations vary according to the stratigraphic position. Reflectance indicates that the coal range gradually decreases from highly volatile bituminous $\mathrm{C}$ (Chipaque formation) to subbituminous C (San Fernando formation). The microlithotypes with the highest concentrations are clarite and vitrinertoliptite. Maceral composition and coal facies indicate changes in the depositional conditions of the sequence. The precursor peat from Late Cretaceous to Late Paleocene accumulated under limnic conditions followed by telmatic in Late Eocene-Early Miocene. The coal facies indices show wet conditions in forest swamps with variations in the flooding surface, influxes of brackish water and good tissue preservation. The tectonic conditions along the Piedemonte Llanero basin is evident, from post-rift to foreland basin, evidenced by oxic and anoxic periods reflected in the maceral composition and its morphology. The coal environment corresponds to an estuarine system started in the Chipaque formation evolving to the lacustrine conditions in the San Fernando formation.
\end{abstract}

Keywords Eastern cordillera basin $\cdot$ Northern Andes $\cdot$ Coal · Organic petrology

\section{Introduction}

Coal is one of the main commodities of the Colombian economy. During 2019, the reported reserves were 4881 million tons of bituminous and anthracitic coal. Colombia is the major coal producer in South and Central America, and the sixth coal exporter country to Europe (BP 2019). The country has twelve coal zones, and the

Clara Guatame

cguatame@sgc.gov.co; clara_guatame@hotmail.com

Marco Rincón

mrincon@sgc.gov.co

1 Servicio Geológico Colombiano, diagonal 53 n. ${ }^{\circ}$ 34-53, Bogotá, Colombia
Piedemonte Llanero zone is the least known considering coal resources (Ingeominas 2004).

Coal petrology reveals the geological and genetic conditions, it is used to obtain the range, distribution, lateral continuity, thickness, and organic and mineral matter composition, as the product of the different active processes during the coal formation (e.g. Teichmüller and Teichmüller 1982; Diessel 1986, 1992; Mukhopadhyay 1986; Calder et al. 1991; Singh and Singh 1996; Taylor et al. 1998; Singh and Singh 2000; Rimmer et al. 2000; Staub 2002; Suarez et al. 2012; Singh et al. 2013; Bechtel et al. 2014; Sen et al. 2016; Singh 2016).

Determining the sedimentary environment of the coal is important in areas of scarce or without exploration studies. This topic improves the geological knowledge and 
provides elements to the research analysis of other resources associated with organic matter and in the use optimization.

The "coal facies" concept is from coal composition, including lithotypes, macerals, maceral indices, microlithotypes and organic geochemistry as a function of the peat-forming flora type (e.g. Singh et al. 2016; Dai et al. 2020). Many petrologists have contributed to the evaluation of factors such as climate, the water table, nutrient supply, and water chemistry as the factors that control the development of peat (e.g. Diessel 1986; Calder et al. 1991, 1993; Suárez et al. 2012; Singh 2016). Research groups (e.g. Suarez et al. 2012; Sen et al. 2016; Dai et al. 2020) have carried out critical reviews that discuss various aspects of environmental reconstruction from macerals, microlithotypes, models, and petrographic indices.

In Colombia, the coal petrology has been applied in some carboniferous areas. Cundinamarca Zone is located in the Eastern Cordillera, the petrographic results show the paralic transgressive to limno-telmatic environments for the bituminous coals of the Guaduas Formation during the Maastrichtian-Paleocene (Guatame and Sarmiento 2004; Mejía et al. 2006; Gómez and López 2017). In the western flank of the Central Cordillera, Castaño and Gómez (2001) carried out a coal petrology analysis for the AntioquiaAntiguo Caldas Zone, they determined a fluvial environment with possible meandric currents for the low-rank coals of the Miocene-Pliocene Aranzazu volcano-clastic sequence, classified them as lignite to $\mathrm{C}$ sub-bituminous. For the same zone, in the Amagá-Nechí sector, Blandón 2007 determined an estuarine and lower delta depositional environment for the sub-bituminous coals of the Amaga Formation (Late Oligocene-Early Miocene). Whereas, in the Los Cuervos Formation from the Calenturitas and La Jagua coal mines in the Cesar zone, Guo et al. 2018 determined ombrogenic conditions without marine influence during most of the time of peat deposition, which are also deduced from the sub-bituminous coals.

Stratigraphic, sedimentological and palynological studies have been carried out in the Piedemonte Llanero (e.g. Ingeominas 2004; Monroy and Sandoval 2017; Monroy and Patiño 2018, van der Hammen 1958; Ulloa and Rodríguez 1976b; Sarmiento 1992; Guerrero and Sarmiento 1996; Pardo 2004; Dueñas and van der Hammen 2007; Bayona et al. 2007; Bayona et al. 2008; Parra et al. 2009; Jaramillo et al. 2011; Pardo and Jaramillo 2014; Caballero et al. 2020), mainly focused on oil and gas resources, without considering coal petrology yet. Therefore, there is a partial knowledge in the composition of the organic and mineral matter in the coal seams, and about the origin and formation facies, which is necessary for the exploration of new economic alternatives in the area.
The main objective of this work is then to carry out a systematic petrological analysis to determine the deposit environment of the Piedemonte Llanero coals, from the Late Cretaceous to the Middle Miocene age, in the Chipaque, Grupo Palmichal, Arcillas del Limbo, and San Fernando formations. The research is also aimed at providing essential technical elements from the coal petrology for future studies related to the basin evaluation, considering the coal as an unconventional deposit, and potential association with rare earth elements, among other investigations.

We validate the importance of knowledge growth through interdisciplinary work with other research lines, such as stratigraphy and palynology, which leads to a more robust restoration of the deposit environment and the origin of the vegetal matter.

\section{Geological frame}

The Piedemonte Llanero is located in the eastern foothills of the Eastern Cordillera Basin, which was configured in an asymmetric graben under marine conditions near the coast with an alternation to continental deposits; and besides affected by different events that caused tectonic inversion, especially from the early Eocene to Oligocene (Barrero et al. 2007). The main regional structures (SW-NE) in the area are the Boquerón, Recetor, Porvenir, Nazareth, and Río Amarillo synclines, located between the thrust fault system of Tesalia to the west and Guaicáramo to the east.

The coal formations correspond in age from the Upper Cretaceous to the Neogene. The sedimentary sequence began with the Chipaque Formation (Upper CenomanianSantonian in Terraza et al. 2013) and consists of shale and claystone with thin sandstones interbedded, which, towards the top, become more frequent and are observed in more than $2 \mathrm{~m}$ thick, with sets up to $25 \mathrm{~m}$. Seven coal seams are identified in the lower part of the formation, numbered M101 at the base and M107 to the top. The seams thicknesses vary from 0.4 to $1.80 \mathrm{~m}$ (Monroy and Patiño 2018). For the Maastrichtian-Lower Palaeocene interval, the nomenclature of the Palmichal Group (Ulloa 1976b) was adopted in this paper, although different authors have found controversial given its equivalences with other formal units as Guadalupe Group and Guaduas Formation (Guerrero and Sarmiento 1996; Terraza et al. 2013). The base of the Palmichal Formation consists of three thick levels of white, medium-grain, and good selection sandstones in medium to very thick beds, with intercalations of grey to dark-grey claystone and siltstone levels, and thinner levels of medium-grained sandstone in thin to medium beds. Towards the top, this formation comprises banks of yellow, medium to coarse-grained sandstones with poor 
selection and quartz crystals reaching $5 \mathrm{~mm}$ in diameter (Monroy and Sandoval 2017). The thicknesses of the coal seam vary between 0.40 and $0.92 \mathrm{~m}$ in the sector of JaguaHumea (Monroy and Patiño 2018). The age of the formation is Early Campanian to Paleocene (Terraza et al. 2013).

The Paleocene comprises the Arcillas del Limbo Formation (Van der Hammen 1958, 1960; Monroy and Sandoval 2017), a sequence characterized by grey, reddish, and green claystone, and a thick succession of white and yellow sandstones bands. Additionally, there are coal-ribbons and seams that are stratigraphically located in the lower and middle sections of the sequence. The M201, M202 seams vary in thickness between 0.4 to $0.8 \mathrm{~m}$ and 0.9 to $1.6 \mathrm{~m}$, respectively; and for the coal-ribbons vary between 0.15 to $0.35 \mathrm{~m}$ (Monroy and Sandoval 2016). The San Fernando Formation was dated from the late Eocene-Oligocene (van der Hammen 1958), or Middle Miocene for the upper segment according to Dueñas and van der Hammen (2007), who correlate it with the León Formation of the Catatumbo Basin. Furthermore, the unit is coeval with the Carbonera Formation, a name given by the oil companies and divided among eight members, from $\mathrm{C} 1$ to $\mathrm{C} 8$ (Bayona et al. 2007, 2008; Parra et al. 2009; Pardo and Jaramillo 2014; Caballero et al. 2020). The formation consists of grey claystone with sandstones of medium to coarse grains interbedded in banks up to $3 \mathrm{~m}$ thick. Five coal seams (M301 to M305) were defined from 0.4 to $1.1 \mathrm{~m}$ of thicknesses (Monroy and Sandoval 2017), as shown in Fig. 1.

\section{Methodology}

The chemical and petrographic features of 15 coal seams of the Piedemonte Llanero were analyzed in the Chemical Laboratory-Servicio Geológico Colombiano. Representative samples of the coal seams were collected in outcrops and mining front throughout the study area, in the sedimentary sequence from Late Cretaceous to Middle Miocene. The samples were homogenized and quartered to obtain representative examples. Then, crushed in $0.85 \mathrm{~mm}$ and $0.25 \mathrm{~mm}$ sizes, to carry out petrographic and chemical analyzes, respectively.

The methods used for the chemical characterization of the coal samples were: (1) proximate analysis for the determination of humidity, ash, volatile matter, and fixed carbon in a LECO TGA-601 and TGA-701 equipment. (2) ultimate analysis for the determination of carbon (C), hydrogen $(\mathrm{H})$, nitrogen $(\mathrm{N})$ and total sulfur $(\mathrm{St})$ percentage in a CHN LECO TRUSPEC equipment in accordance with the international standards (ASTM D388-99 1999; ISO 11,760-2005). From the $\mathrm{C}, \mathrm{H}$, and $\mathrm{O}$ percentage, the atomic radius was calculated and plotted on the Van
Krevelen diagram (Tissot and Welte 1978) to identify the kerogen type.

Microscopic observations were made in polished pellets, prepared following ASTM D2797 norm, to measure the reflectance of the vitrinite, identify and quantify organic components and inorganic matter present in the coal samples.

Reflectance measurements were performed on the Olympus BX-51 microscope and with the TIDAS-MSP 400 CCD VIS/NIR spectrophotometer. For the counting of macerals and microlithotypes, the Leitz Ortholux II POLMK microscope was used, with a minimum magnification of 400 diameters, a point counter, and a mechanical stage that allows advancing in defined fixed increments.

The reflectance analysis $\left(\% R_{\mathrm{o}}\right)$ consists of 100 measurement points in Vitrinite. The quantitative and qualitative macerals observation under reflected light and fluorescence include counting of 500 points according to the classification given in the compilation of ICCP 1998, 2001, and from Pickel et al. 2017 of the Liptinite Group. The procedure was carried out according to ISO 7404/3 (2009), ASTM D2799-05a, and D2798-05b standards.

The results section shows the description by maceral groups, while the figures were organized with microphotographs by geological formation to illustrate in an integral way their different petrographic properties.

For microlithotypes analysis, 500 points were counted with the grid of 20 intersections as indicated in the ISO 7404/4 (1988) standard and the classification given in ICCP 1963, 1971, in Suárez and Crelling (2008) and Taylor et al. 1998.

The facies and the deposit environment of the coals were identified from the petrographic models (Smyth 1979; Mukhopadhyay 1986; Calder et al. 1991; Diessel 1992; Singh and Singh 1996; Rimmer et al. 2000; Singh and Singh 2000; Singh et al. 2013), and the GI, TPI, GWI and VI indices.

\section{Results}

\subsection{Coal rank and type of kerogen}

The Chipaque Formation coals (Late Cretaceous) are classified as High Volatile Bituminous. For the Arcillas del Limbo Formation (M201- M202) the rank coal is subbituminous A, while those of the San Fernando Formation were classified as subbituminous A, B, and C- M301M305 (Table 1). The total coal seams are Type III. The lower $\mathrm{O} / \mathrm{C}$ atomic ratios are related to the higher carbonization rank, indicating that in the Piedemonte Llanero coals the rank decreases as the units got younger (Fig. 2). 


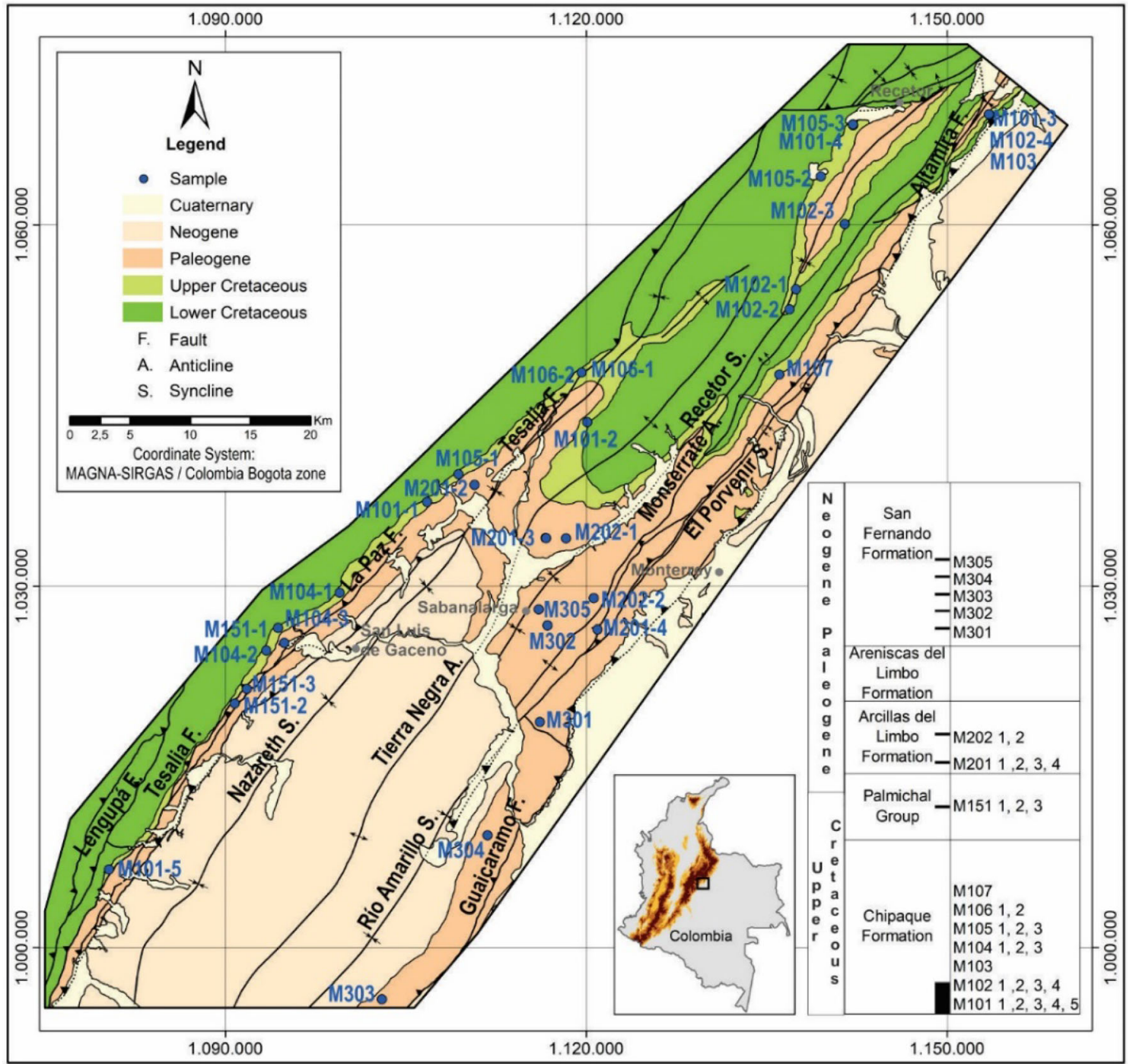

Fig. 1 Geological map and location of Piedemonte Llanero coals in the Eastern Cordillera of Colombia

In the same sense, the analysis shows that increasing the oxygen concentration decreases the coal rank, while the percentage of hydrogen indicates the kerogen type.

\subsection{Maceral and micro-lithotype analysis}

Huminite-Vitrinite is the dominant macerals group, showing a gradual percentage increase from the Palmichal Group to the San Fernando Formation. Macerals of the liptinite group are found in higher percentages in the middle section of the stratigraphic column (Arcillas del Limbo Formation and Palmichal Group), and the percentage of macerals of the Inertinite group is higher in the coals of the Palmichal Group (Fig. 3, Table 2).

\subsubsection{Huminite-vitrinite group}

The quantitative distribution, in which coals are mainly vitrinitic, with the telovitrinite and telohuminite as the dominant's subgroups depending on the rank coals (Table 2). Collotelinite is in thick bands and is the predominant maceral of the Chipaque Formation and the Palmichal Group (Figs. 4h, j; 5c). Occasionally, cracks and marks are observed of the oxidized coal (Fig. 4k). The corpogelinite shows isolated bodies with oval and rounded shapes or filling empty spaces (Fig. 5e, f). The gelinite is observed in homogeneous appearance, filling cavities without a defined structure, it reflects an advanced process of devolatilization (Figs. 5e, 6e). The collodetrinite is seen as a groundmass that involves other macerals (Figs. 41, 5i), while the vitrodetrinite as small particles of vitrinite of variable shapes (Fig. 51). 
Table 1 Physicochemical results (wt $\%)$ and reflectance measurement $(\%)$ of Piedemonte Llanero coals in the Eastern Cordillera of Colombia

\begin{tabular}{|c|c|c|c|c|c|c|c|c|c|c|c|}
\hline \multirow[t]{3}{*}{ Item } & \multicolumn{11}{|l|}{ Chipaque Formation } \\
\hline & \multicolumn{3}{|l|}{ M101 } & \multirow{2}{*}{ M103 } & M104 & \multicolumn{3}{|c|}{ M105 } & \multicolumn{2}{|l|}{ M106 } & M107 \\
\hline & \multicolumn{10}{|l|}{ HVBC-HVBA } & \\
\hline$R_{\mathrm{o}}(\%)$ & $0.53-0.95^{\mathrm{a}}(0.69)^{\mathrm{b}}$ & \multicolumn{2}{|c|}{$0.56-0.77(0.70)$} & 0.57 & 0.55 & \multicolumn{3}{|c|}{$0.90-1.00(0.95)$} & \multicolumn{2}{|c|}{0.9} & 0.64 \\
\hline Ash (\%) & $2.75-7.09(5.47)$ & \multicolumn{2}{|c|}{$1.86-3.01(2.53)$} & 0.85 & $5.38-9.04(6.02)$ & \multicolumn{3}{|c|}{$2.44-8.60(6.67)$} & \multicolumn{2}{|c|}{$1.78-1.96(1.87)$} & 19.08 \\
\hline VM (\%) & $31.49-45.09(37.20)$ & \multicolumn{2}{|c|}{$35.80-43.85(38.20)$} & 43.4 & $38.21-41.85(40.19)$ & \multicolumn{3}{|c|}{$32.27-35.52(33.84)$} & \multicolumn{2}{|c|}{$33.8-34.35(34.07)$} & 34.37 \\
\hline $\mathrm{FC}(\%)$ & $47.98-60.64(54.65)$ & \multicolumn{2}{|c|}{$53.15-62.35(59.26)$} & 53.76 & $48.14-52.57(50.28)$ & \multicolumn{3}{|c|}{$54.30-59.19(56.74)$} & \multicolumn{2}{|c|}{$62.31-62.8(62.55)$} & 46.55 \\
\hline $\begin{array}{l}\text { CV (Btu/ } \\
\text { lb) }\end{array}$ & $\begin{array}{c}11,183-14,437 \\
(13,265)\end{array}$ & \multicolumn{2}{|c|}{$\begin{array}{c}13,559-14,549 \\
(13,965)\end{array}$} & 13,933 & $\begin{array}{c}12,982-14,428 \\
(13,612)\end{array}$ & \multicolumn{3}{|c|}{$\begin{array}{c}13,216-15,054 \\
(13,926)\end{array}$} & \multicolumn{2}{|c|}{$\begin{array}{c}14,751-14,773 \\
(14,762)\end{array}$} & 12,009 \\
\hline TS $(\%)$ & $0.39-1.41(0.82)$ & \multicolumn{2}{|c|}{$0.42-0.76(0.65)$} & 0.44 & $0.59-2(1.14)$ & \multicolumn{3}{|c|}{$0.69-1.16(0.87)$} & \multicolumn{2}{|c|}{$0.64-0.65(0.64)$} & 1.02 \\
\hline $\mathrm{C}(\%)$ & $66.97-80.65(74.73)$ & \multicolumn{2}{|c|}{ 75.9-80.67 (78.0) } & 75.93 & $72.03-74.73(73.49)$ & \multicolumn{3}{|c|}{$75.35-83.28$ (78.25) } & \multicolumn{2}{|c|}{$82.02-83.04(82.53)$} & 67.16 \\
\hline $\mathrm{H}(\%)$ & $4.67-5.89(5.28)$ & \multicolumn{2}{|c|}{$5.24-5.77(5.41)$} & 5.77 & $5.38-5.5(5.43)$ & $4.8-5$ & $6(5.21)$ & & $5.52-5.61$ & $.56)$ & 5.03 \\
\hline $\mathrm{O}(\%)$ & $4.53-20.2(11.54)$ & $9.01-$ & $13.74(11.73)$ & 5.82 & $10.04-12.14(11.27)$ & $8.16-$ & $0.49(8$. & & $7.0-7.86(7$ & 43) & 6.41 \\
\hline Item & Palmichal Group & & Arcillas del L & imbo Form & nation & & San $\mathrm{F}$ & ando $\mathrm{fc}$ & formation & & \\
\hline & M151 & & M201 & & M202 & & M301 & M302 & M303 & M304 & M305 \\
\hline & HVBC & & SUBA & & & & SUBA- & SUBC & & & \\
\hline$R_{\mathrm{O}}(\%)$ & 0.5 & & $0.43-0.58(0$. & & $0.48-0.50(0.49)$ & & 0.63 & 0.61 & 0.41 & 0.42 & 0.54 \\
\hline Ash (\%) & $7.05-12.12(9.40)$ & & $2.08-6.62(5$. & & $5.16-6.12(5.64)$ & & 15.19 & 4.76 & 23.81 & 12.76 & 18.83 \\
\hline VM (\%) & 37.89- $39.15(37.8$ & & $40.99-43.2$ & 1.94) & $42.87-44.05$ & & 39 & 42.51 & 31.08 & 37.7 & 38.22 \\
\hline $\mathrm{FC}(\%)$ & $43.68-48.22(45.6$ & & $42.12-49.19$ & 45.99) & $50.80-51.02(50.91$ & & 38.81 & 45.75 & 39.11 & 44.3 & 34.23 \\
\hline $\mathrm{CV}(\mathrm{Btu} / \mathrm{lb})$ & $11,102-11,346(11$ & ,192) & $10,633-12,45$ & $3(11,974)$ & $10,924-11,517$ (11 & ,220) & 9965 & 11,917 & 8380 & 10,382 & 8686 \\
\hline TS (\%) & $0.58-0.94(0.72)$ & & $0.32-1.61(0$ & & $0.35-0.40(0.37)$ & & 0.85 & 2.93 & 1.67 & 4.08 & 4.1 \\
\hline $\mathrm{C}(\%)$ & $63.35-65.93)(64.8$ & & $64.71-71.56$ & $69.00)$ & $58.32-69.66(63.9)$ & & 58.63 & 67.83 & 49.02 & 59.65 & 49.53 \\
\hline $\mathrm{H}(\%)$ & $4.99-5.26(5.15)$ & & $5.38-5.63$ & & $5.11-5.62(5.36)$ & & 4.87 & 5.55 & 4.5 & 5.15 & 4.87 \\
\hline $\mathrm{O}(\%)$ & $17.21-20.2(18.68)$ & & $16.3-19.59$ & 7.86) & $16.3-30.74(23.52)$ & & 19.21 & 17.53 & 20.01 & 17.11 & 21.7 \\
\hline
\end{tabular}

HVBC High volatile bituminous C; $H V B A$ high volatile bituminous A; SUBA subbituminous A; SUBC subbituminous C

$R_{o}$ mean Mean vitrinite reflectance; $V M$ volatile matter; $F C$ fixed carbon; $C V$ calorific value; $T S$ total sulfur

${ }^{\mathrm{a}}$ Concentration range. ${ }^{\mathrm{b}}$ Mean values

Telohuminite is the main subgroup of the Arcillas del Limbo and the San Fernando Formation, with Ulminite as the dominance maceral, which is observed in homogenous bands of variable thickness, with cracks and fractures filled with mineral matter, mainly clay (Figs. 6d, g, j, k, 1; 7a, e, 1). The proportion of the detrohuminite and gelohuminite subgroups is significant, with the maceral prevalence of the densinite and corpohuminite, this is characterized by an oval or sub-rounded shape and is filling the empty spaces of a pre-existing matrix (Figs. 6g, 7j). Textinite is identified by its well-preserved cellular structure (Figs. $6 \mathrm{~h} ; 7 \mathrm{~b}, \mathrm{k}$ ). The lumens are observed as oval bodies and filled of gelohuminite and mineral matter mainly. The attrinite shows particle sizes $<10$ microns, with clay filling of the empty spaces between fragments (Fig. $7 \mathrm{~h}$ ).

\subsubsection{Liptinite group}

Sporinite is observed as microsporinite and megasporinite, with well-preserved individual bodies of Tenuisporinite (thin-walled), in parallel arrangement to the bedding plane thick (Fig. 7a, c, j), and jagged walled (Fig. 6a, b, c). The internal morphology is occasionally identified (Figs. 4i; $5 \mathrm{~g}$ ). Spores sacs (sporangium) occurs in lenticular to elongated bodies, reddish-brown colour under reflected light observations, and yellow colour under fluorescent light, highlighting their internal morphology (Figs. 4t; 7g).

Cutinite is observed both in thin-walled (tenuicutinite) and thick-walled (crassicutinite), the edges are jagged and orange colour under fluorescent light in the San Fernando Formation (Fig. 7d). In the Chipaque Formation, the crassicutinite is deformed (Fig. $4 \mathrm{~d}, \mathrm{~g}, \mathrm{r}$ ), while the Palmichal Group is characterized by tenuicutinite well-preserved with jagged edges (Fig. 5c, 1). It can be deformed and is observed toward the borders of the collotelinite, occasionally.

Liptodetrinite occurs as fragments of other liptinitic macerals. Pollen is also found without defined shapes.

Alginite appears as colonies of Botryococcus and shows spherical, ovoid shapes, or fan-shaped (Palmichal Group 


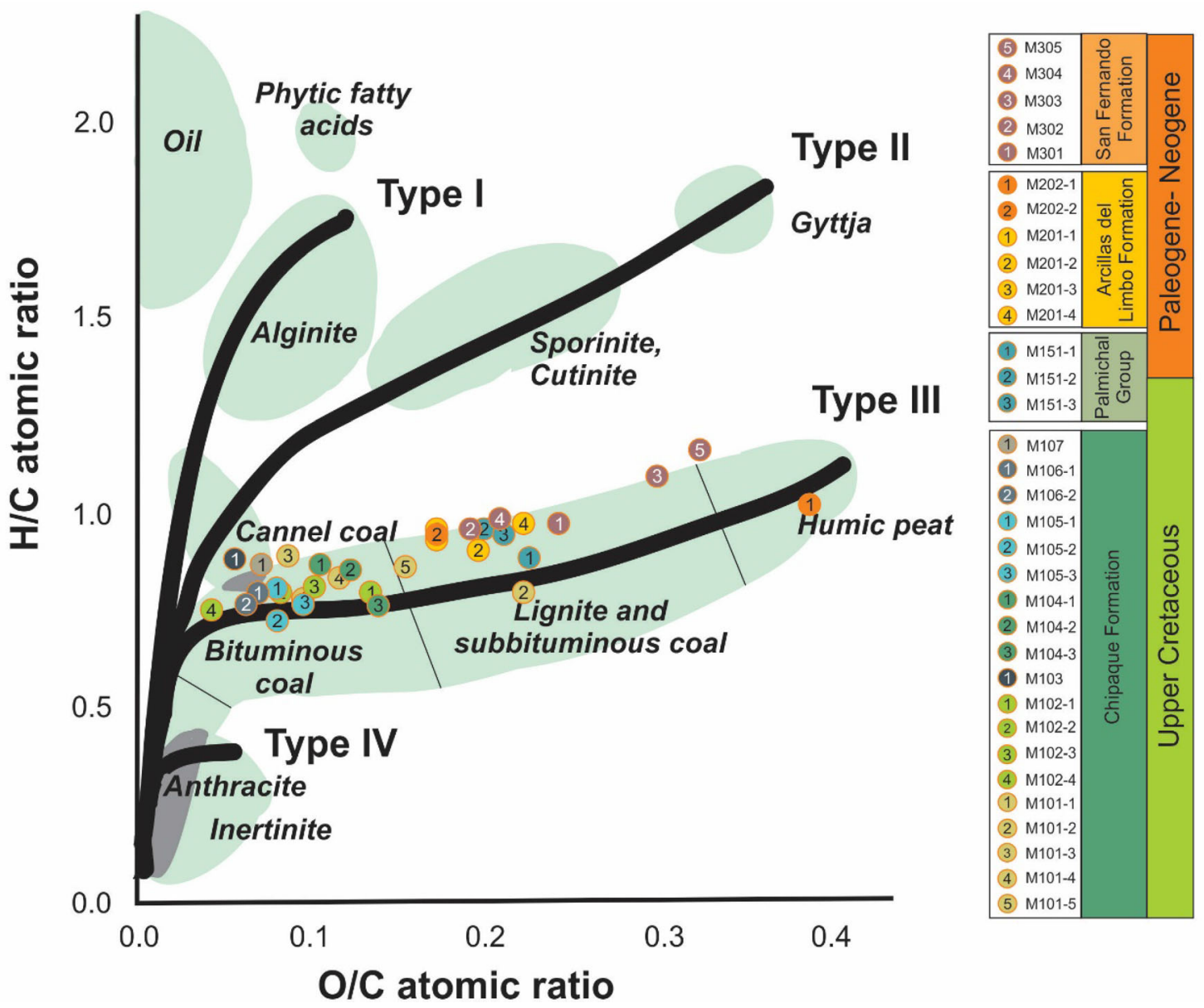

Fig. 2 Type of kerogen, coal classification, and maceral composition of Piedemonte Llanero coals. (Van Krevelen diagram 1961, 1993) Modified from Cornelius 1978, in Suárez and Crelling, 2008

and San Fernando Formation). It is of planktonic origin, united by a gelatinous tissue and, it is typical of lacustrine environments (Figs. 5h; 7f).

Fluorinite occurs as sub-round shapes in continuous layers or filling cavities. It is observed the bright yellow colour under fluorescent light. It is frequently associated with cutinite (Figs. 5b; 7i).

Chlorophyllinite is from chloroplasts, fluorescence is red. It is observed in low proportion and reveals anaerobic conditions (Fig. 4a).

Between the secondary macerals, resinite occurs filling cracks and empty spaces or replacing other macerals with a rounded edge. It emits an intense yellow-orange fluorescence and has no an internal structure (Figs. 4q; 5f; 6b, c, i, $\mathrm{k}, 1 ; 7 \mathrm{c})$. Bituminite appears as amorphous or a sub-rounded elongated groundmass, occasionally attached to other macerals (Fig. 5m). Another secondary maceral is exudatinite, which occurs filling spaces empty of fusinite (Figs. 4b; 5d).

\subsubsection{Inertinite group}

Inertodetrinite consists of small remnants fusinitized plants within the peat. It is present in layers parallel to the stratification (Figs. 4c, e, 1, p; 5c; 6b, d, e, g; 7a, b). Fusinite, semifusinite, and funginite detritus are distinguished in the Arcillas del Limbo Formation.

Fusinite and Semifusinite are observed without cell structure since it is not well preserved (Chipaque Formation, Palmichal Group), and with well-preserved cellular structure in the Arcillas del Limbo and San Fernando Formations (Figs. 4b, f; 5d, j; 6f, i).

Funginite is seen as round and oval bodies. Teleutospores (fungal spores) are in low concentration, as groups of single cells in the Arcillas del Limbo Formation, those are indicative of few bacterial activities (Fig. 6a, c, f, k, l). It is identified in colonies or crushed, as bands parallel to the stratification or agglomerated (Fig. 6d, k). Sclerotia's empty spaces, in the San Fernando Formation, can be filled with exudatinite or mineral matter (Fig. 7b, e). 

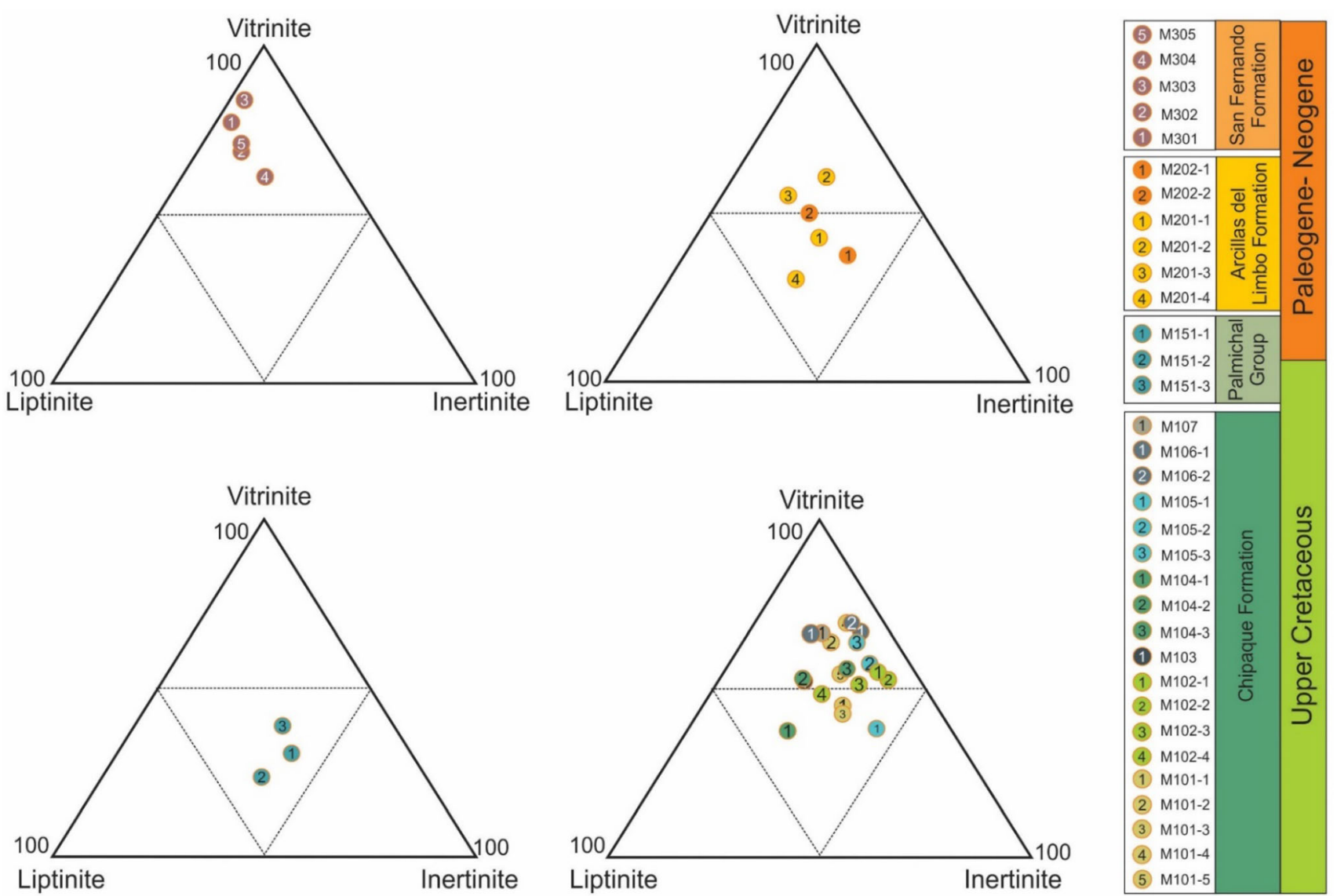

Fig. 3 Maceral composition of Piedemonte Llanero coals in the Eastern Cordillera of Colombia

Micrinite is replacing liptinite macerals, which is observed as bands or as elongated lenses. It has an irregular and sub-rounded form and is associated with mineral matter occasionally (Fig. 4j; Fig. 6j).

Macrinite is distinguished as amorphous bodies of different sizes in the Palmichal Group and the Arcillas del Limbo Formation (Fig. 5d; Fig. 6g).

Mineral matter is composed of sulphide (pyrite) in disseminated, euhedral, and framboidal form, carbonate, and clay; this last occurs as groundmass or filling cracks, fissures, or cleat, and replacing liptinitic macerals (cutinite) (Fig. 4h, n; Fig. 5j; Fig. 7b).

Micro-lithotypes Clarite is the main micro lithotype (bimaceral group) in studied formations, except in the Palmichal Group that is vitrinertoliptite (trimaceral group) because of the high percentage of liptinite in the seams (Table 3).

\section{Interpretation and discussion}

\subsection{Coal facies}

The use of petrographic data as the only source in facies analysis has been controversial by different authors, such as Crosdale 1993, Dehmer 1995, Wüst et al. 2001, Scott 2002, Moore and Shearer (2003), Diessel 2007; Hower and Ruppert (2011), Sahay 2011, Sen et al. 2016, Dai et al. 2020. The present study deals with the facies and the coal deposit environment, obtained from the petrographic indices and models. We argue that the models apply the fundamentals related to the active processes at the time of peat formation, the appearance, and the nature of the maceral groups. We consider the facies concept as"a body of sediment characterized by specific textural, structural, and compositional properties, and definition of the sedimentary environment as characterized by a particular suite of physical, chemical and biologic parameters that operate to produce facies (Boggs 1987). We relate the results of the coal facies with other disciplines such as palynology and stratigraphy, for the deposit environment interpretation, which solve some points. Several models have been 


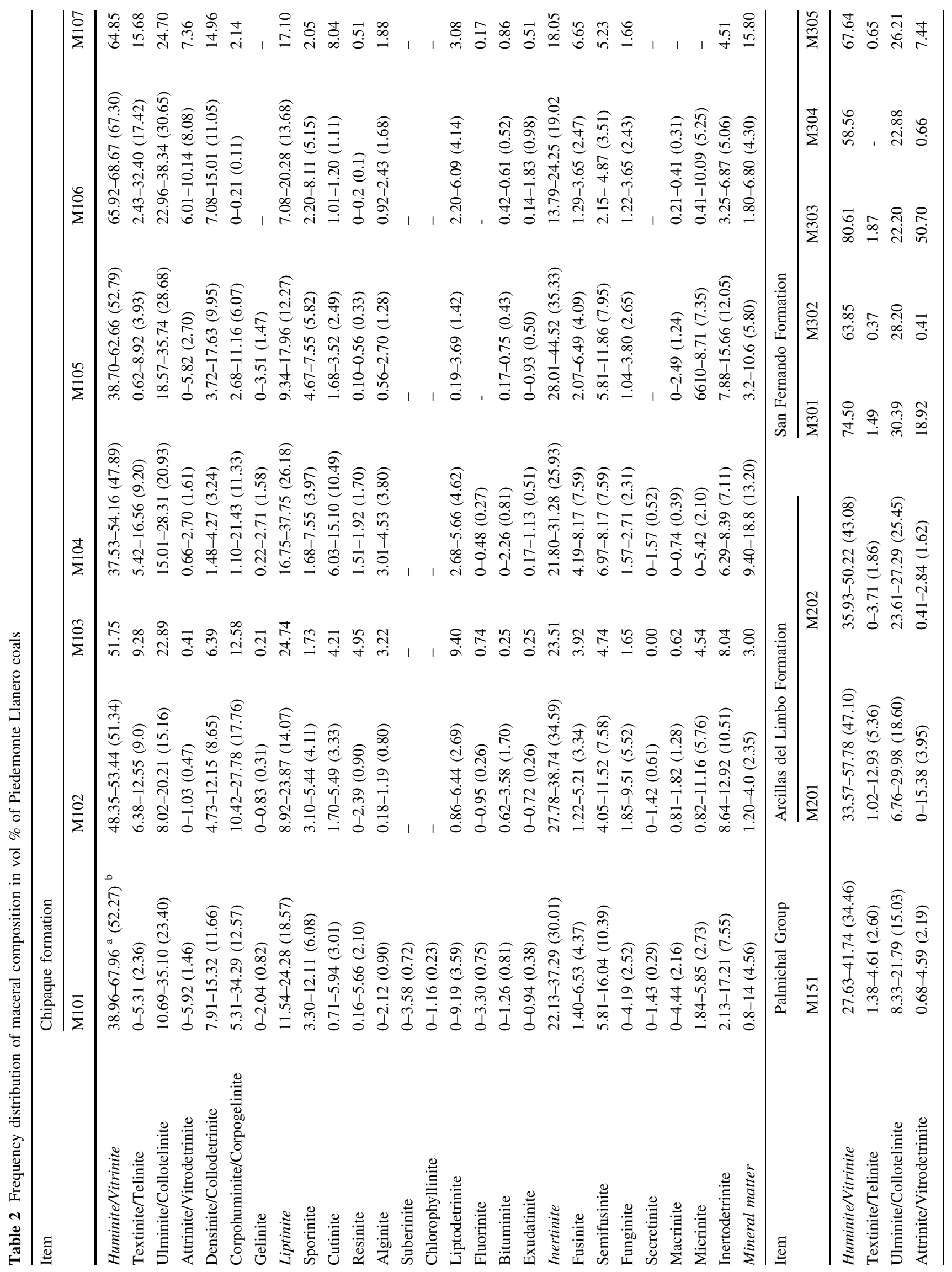




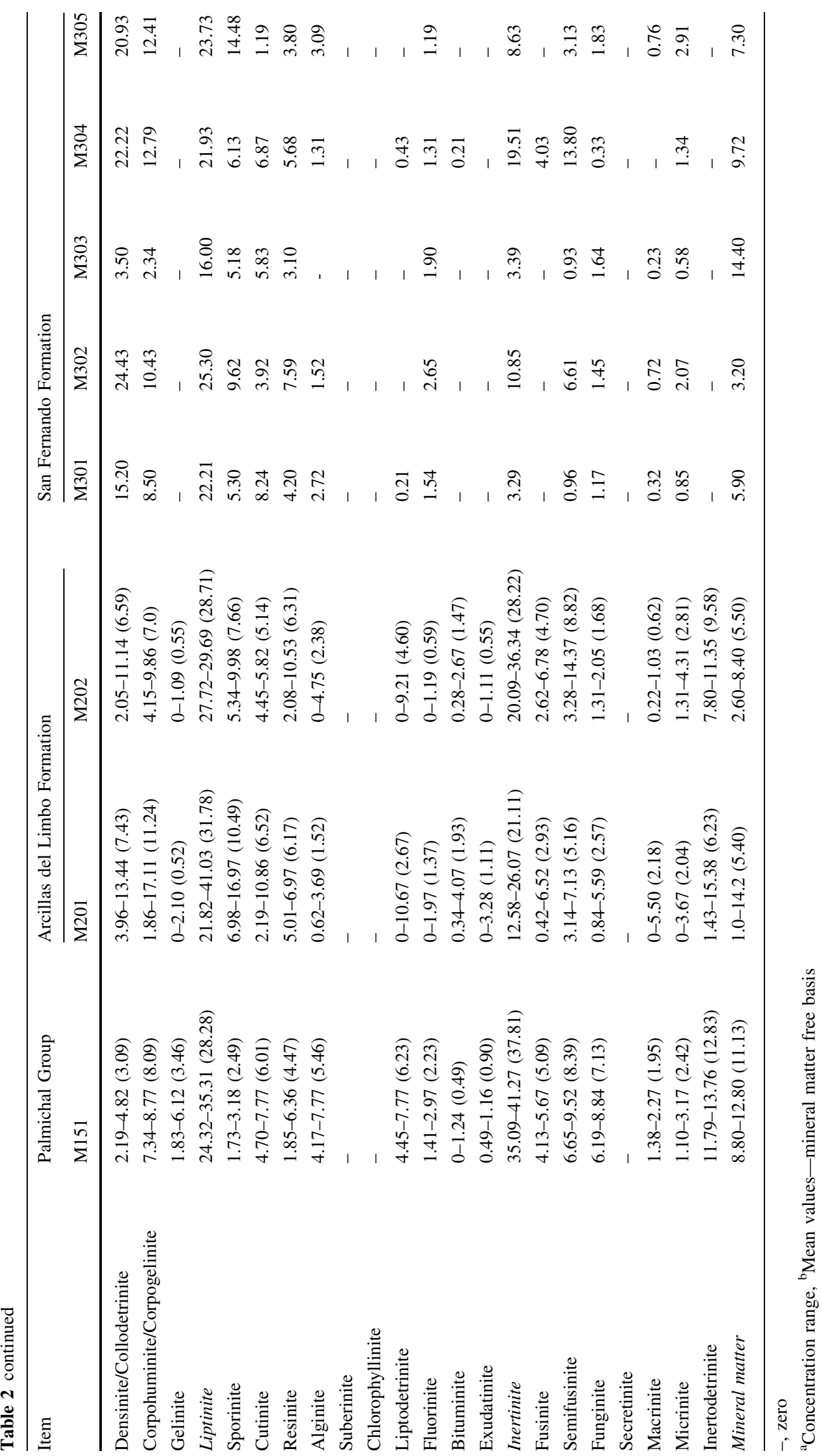



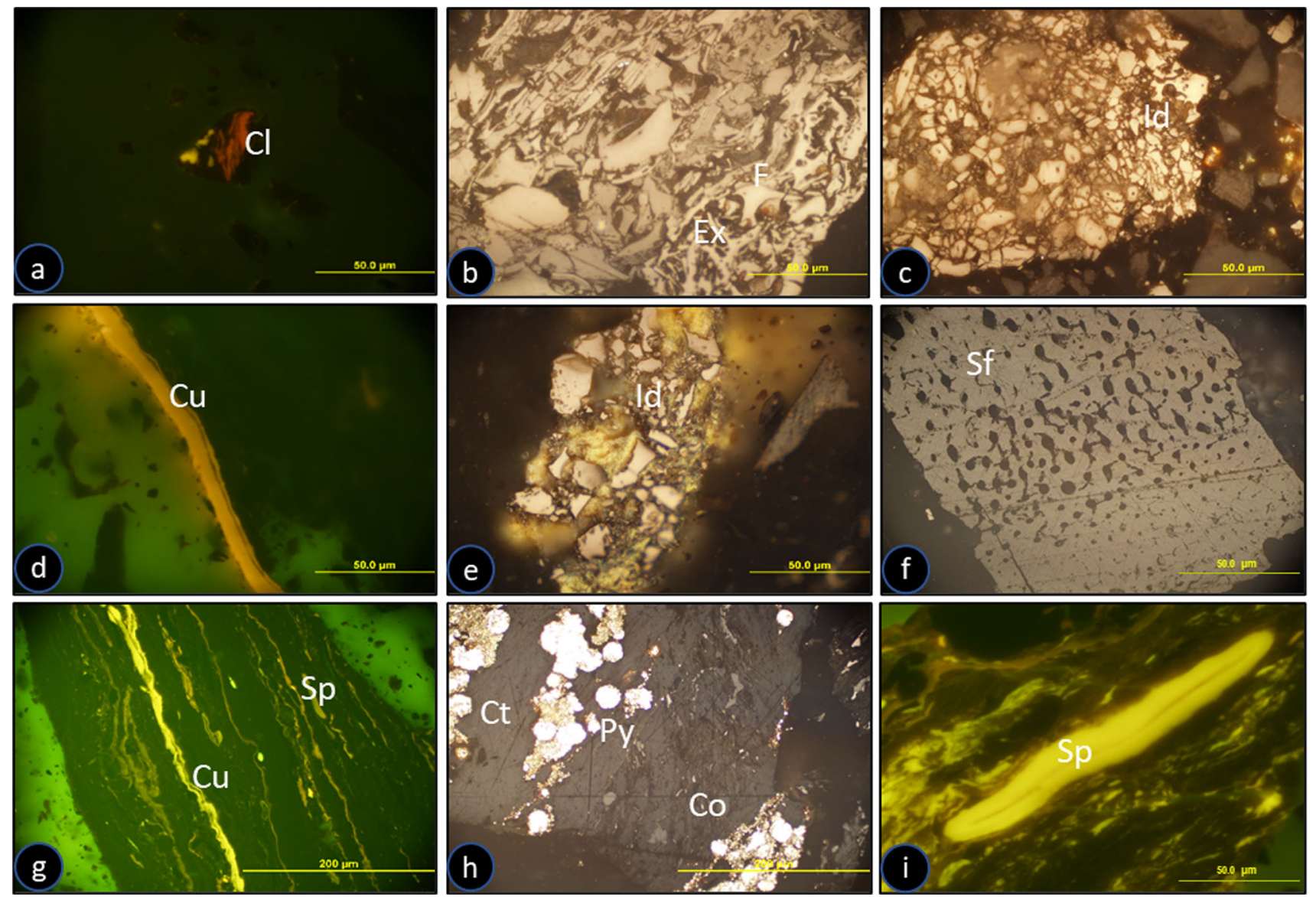

Fig. 4 Microphotographs of macerals of the Chipaque formation. a Chlorophyllinite in M101. b Fusinite, whose empty spaces are filled by exudatinite in M101. c Inertodetrinite in M101-2. d Thick-walled cutinite in M102. e Inertodetrinite embedded in siderite in M102. f Semifusinite degradaded in M103. g Liptinite under fluorescence in M104. h Banding of collotelinite with syngeneic framboidal pyrite in M104. i Thickwalled megaspore in M104. j Bands of collotelinite, micrinite replacing liptinite in M105. k Devolatilized vitrinite in M106. $\mathbf{l}$ Collodetrinite containing inertodetrinite and clay mineral matter in M107. m Bituminite in M101. n Diagenetic pyrite in M101. o Textinite in M103Vitrinite (Vi), Textinite (Tx), Collotelinite (Ct), Collodetrinite (Cd), Fusinite (F), Semifusinite (Sf), Micrinite (Mi), Inertodetrinite (Id), Sporinite, sporangium (Sp), Cutinite (Cu), Resinite (Re), Bituminite (Bi), Chlorophyllinite (Cl), Exudatinite (Ex), Clay mineral matter (Cy), Pyrite matter mineral (Py). Fluorinite (Fl), Pyrite mineral matter (Py). Microphotographs of macerals of the Chipaque formation. p Inertodetrinite in M102. q Resinite in M101. $\mathbf{r}$ Original tissues preserved in M104. s Mosaic of macerals in M103. $\mathbf{t}$ Sporangium in M101. Vitrinite (Vi), Textinite (Tx), Collotelinite (Ct), Collodetrinite (Cd), Fusinite (F), Semifusinite (Sf), Micrinite (Mi), Inertodetrinite (Id), Sporinite, sporangium (Sp), Cutinite $(\mathrm{Cu})$, Resinite $(\mathrm{Re})$, Bituminite $(\mathrm{Bi})$, Chlorophyllinite $(\mathrm{Cl})$, Exudatinite (Ex), Clay mineral matter (Cy), Pyrite matter mineral (Py)

developed from coal composition to interpret the mires environment (Rimmer et al. 2000; Mukhopadhyay 1986; Singh and Singh 1996; Singh and Singh 2000; Singh et al. 2013; Smyth 1979, 1984).

The maceral composition allocated to "genetic" groups, based on processes that may have been active in the formation of peat swamp (Preservation, Degradation or Fusinization) of the Piedemonte Llanero coals applying a facies model proposed by Rimmer et al. 2000, which suggests:-Facies A, as characteristic of the San Fernando Formation, reveals low content of inertinite macerals, higher content of degraded organic matter and moderate of preserved macerals, derived from woody tissue composed of cellulose and lignin (Suarez and Crelling 2008), possibly in a low $\mathrm{pH}$ environment;-Facies B in the Arcillas del
Limbo Formation, the Palmichal Group, and the Chipaque Formation, indicates an intermediate state of preservation and degradation of the organic matter, as a result of alternation of construction and destruction processes in the peat deposit, and variations in the water table;-Facies C has been identified in some seams of the Chipaque Formation that contain a low concentration of liptinite and the highest percentages of collotelinite, as indicators of better conservation of organic matter (Fig. 8).

Based on the maceral composition or microlithotypes, and the criteria used in the classification of peatlands, mainly the influence of the water table, the Mukhopadhyay 1986; Singh et al. 2013 and Singh and Singh (1996) models attempt to understand the redox conditions and the peatforming ecosystems in the past (Figs. 9, 10, 11, 12). In the 

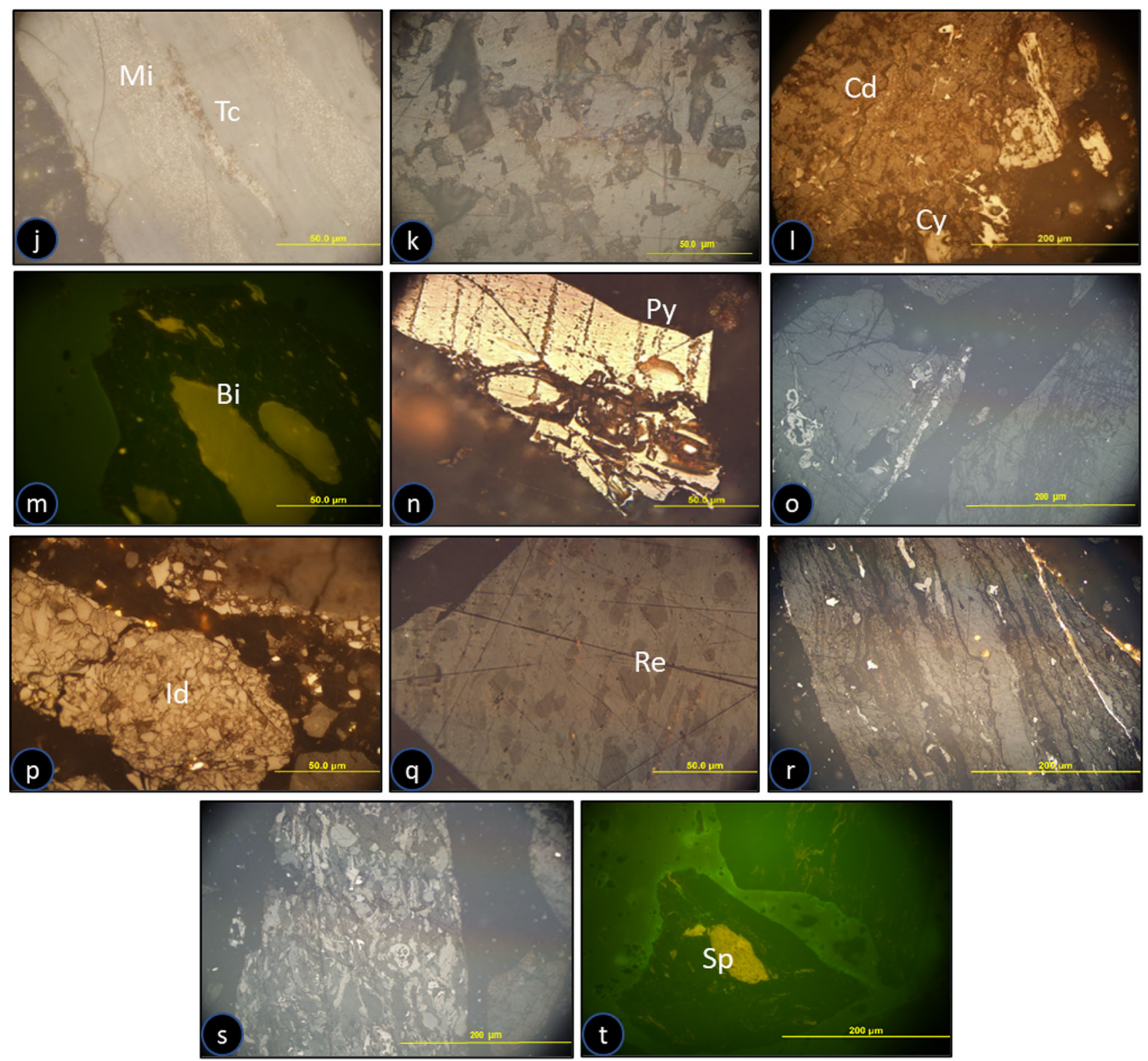

Fig. 4 continued

case of Piedemonte Llanero coals, the models indicate peat formed in a swamp forest to moor-reed plants (low-peat wetlands, like the grass of humid zones) in an open water swamp where the oxic to anoxic conditions prevalence, with good tissue preservation (Mukhopadhyay 1986; Singh and Singh 1996; Singh and Singh 2000, Singh and Singh 2013).

\subsection{Petrographic indexes}

The parameters formulated by Diessel 1985, 1986, 1992 denominated Gelification Index (GI) and Tissue Preservation Index (TPI), have been determined for the analysis of the level water that covers the peat. According to the maceral composition, four accumulation zones are clearly defined: terrestrial, telmatic, limnic and limnotelmatic. The GI and TPI are calculated as under:

$$
\begin{aligned}
\mathrm{GI}= & \text { Vitrinite }+ \text { Macrinite } / \text { Semifusinite }+ \text { Fusinite } \\
& + \text { Inertodetrinite }
\end{aligned}
$$

$$
\begin{aligned}
\text { TPI }= & \text { Telinite }+ \text { Collotelinite }+ \text { Semifusinite } \\
& + \text { Fusinite } / \text { Collodetrinite }+ \text { Macrinite } \\
& + \text { Inertodetrinite }
\end{aligned}
$$

The GI also determines the degree of persistence of wet or dry conditions (Diessel 1992). TPI is the measure that corresponds to the ratio between preserved and not 

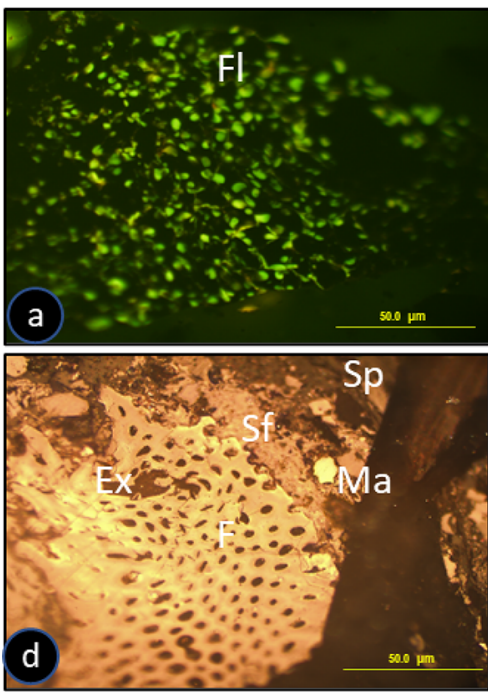

b
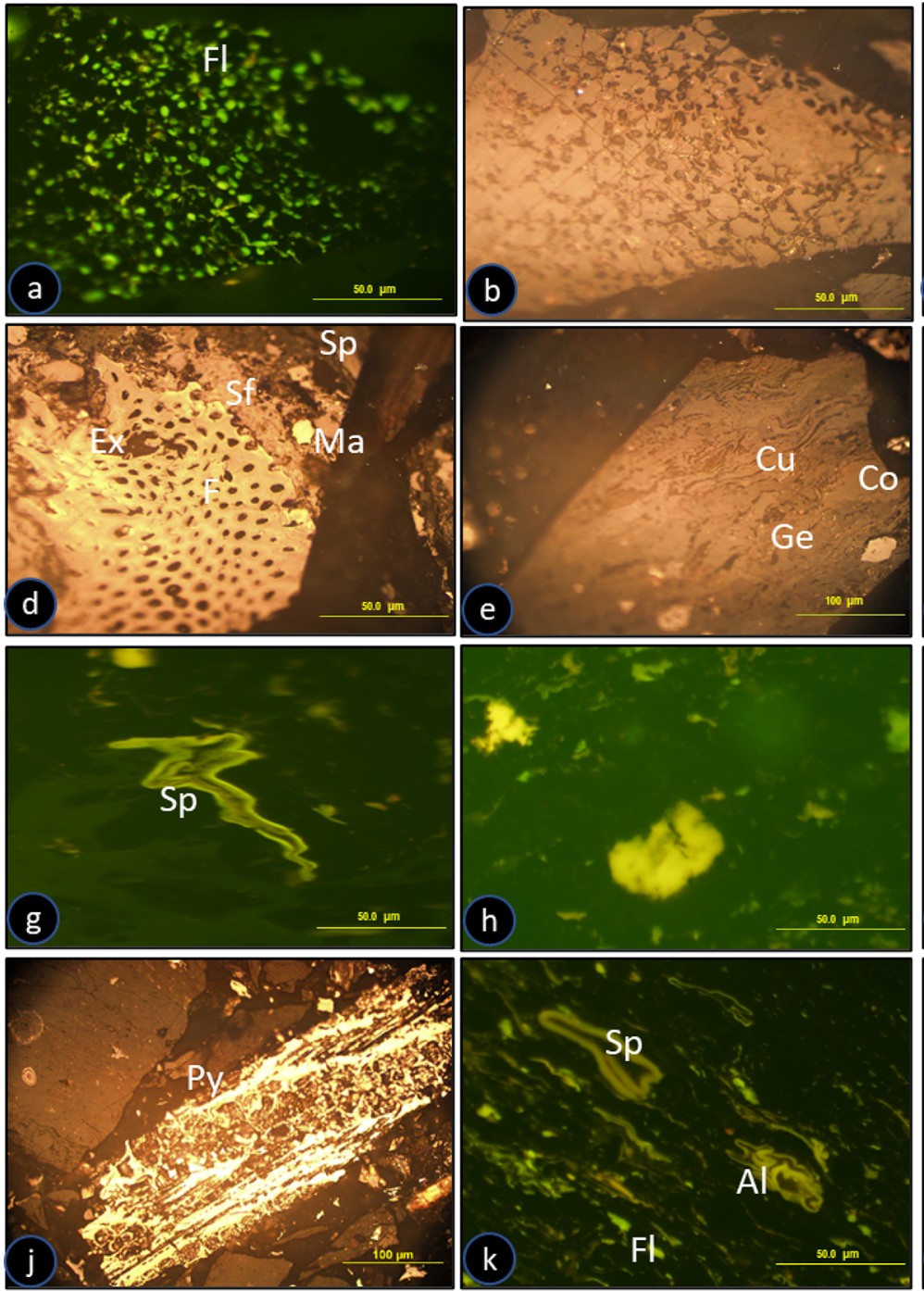
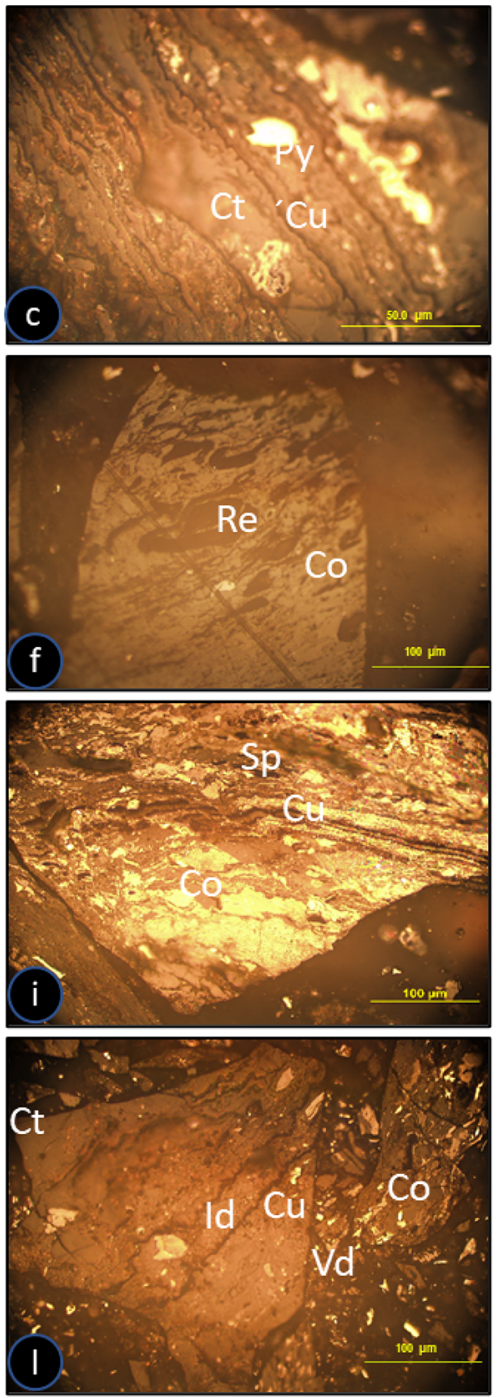

Fig. 5 Microphotographs of Palmichal group macerals. a Fluorinite in M151-3. b Inertinite- semifusinite, macrinite, and fusinite, whose empty spaces are filled by exudatinite in M151-2. c Collotelinite bands, limited by cutinite, and with patches of inertodetrinite. Pyrite epigenetic-early diagenesis in M151-3. d Vitrinite in the process of devolatilization and gelation (corpogelinite) in M151-2. e Gelinite, corpogelinite, and thinwalled cutinite (tenuicutinite) in M151-2. f Corpogelinite and resinite filling voids in M151-2. g Thick-walled megaspore under fluorescence in M151-2. h Alginite and Botryococcus colonies in M151-3. i Inertinite in collodetrinite ground mass, thin-walled cutinite deformed in M151-3. j Epigenetic pyrite and fusinite in M151-3. k Liptinite under fluorescence in M151-3. 1 Inertodetrinite and vitrodetrinite in M151-3. Vitrinite (V), Collotelinite (Ct), Collodetrinite (Cd), Vitrodetrinite (Vd), Corpogelinite (Co), Gelinite (Ge), Fusinite (F), Semifusinite (Sf), Macrinite (Ma), Inertodetrinite (Id), Sporinite (Sp), Cutinite (Cu), Resinite (Re), Alginite (Al), Fluorinite (Fl), Exudatinite (Ex), Pyrite mineral matter (Py) 

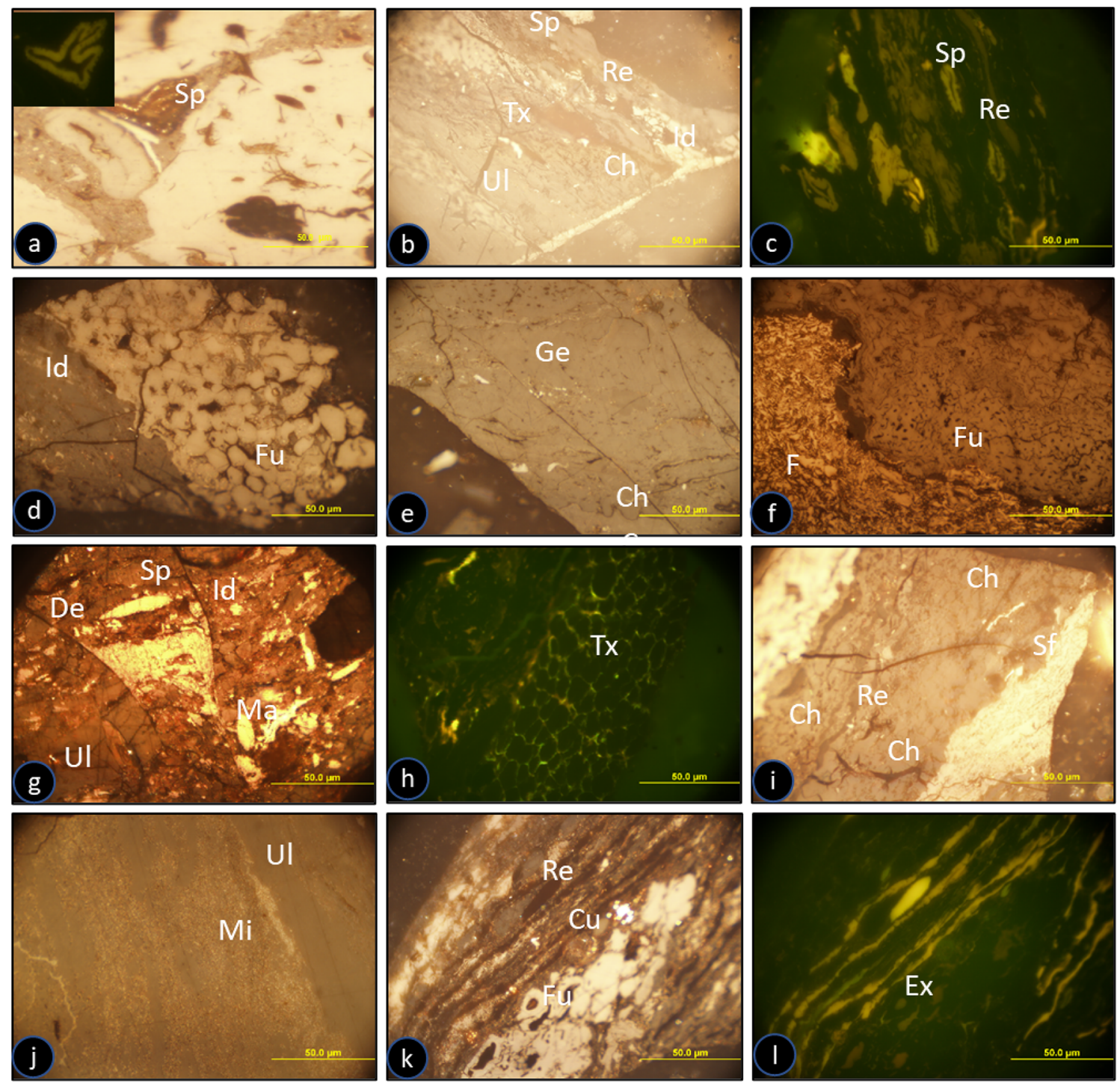

Fig. 6 Microphotographs of macerals of the Arcillas del Limbo formation. a Funginite (teleutospore) and sporinite in M202-2. b Macerals of the huminite group with sporinite, inertodetrinite, and resinite in M201-1. c Sporinite and resinite in M201-1, with fluorescence. d Ulminite band, inertodetrinite, and teleutospore sacs (funginite) in M201-1. e Gelinite, corpohuminite, and inertodetrinite in M201-2. f Fusinite and agglomeration of funginite in M201-2. g Ulminite bands, densinite that surrounds inertodetrinite, macrinite, sporinite, and corpohuminite in M201-4. It is fractured. h Textinite in M201-4. i Corpohuminite, resinite, and semifusinite in M201-1. j Micrinite and ulminite bands in M201-3. k-l Reflected and fluorescent light. Ulminite with corpohuminite, teleutospore (funginite), cutinite and resinite in M201-3. Textinite (Tx), Ulminite (Ul), Densinite (De), Corpohuminite (Ch), Gelinite (Ge), Fusinite (F), Semifusinite (Sf), Funginite (Fu), Macrinite (Ma), Micrinite (Mi), Inertodetrinite (Id), Sporinite (Sp), Cutinite (Cu), Resinite (Re) 

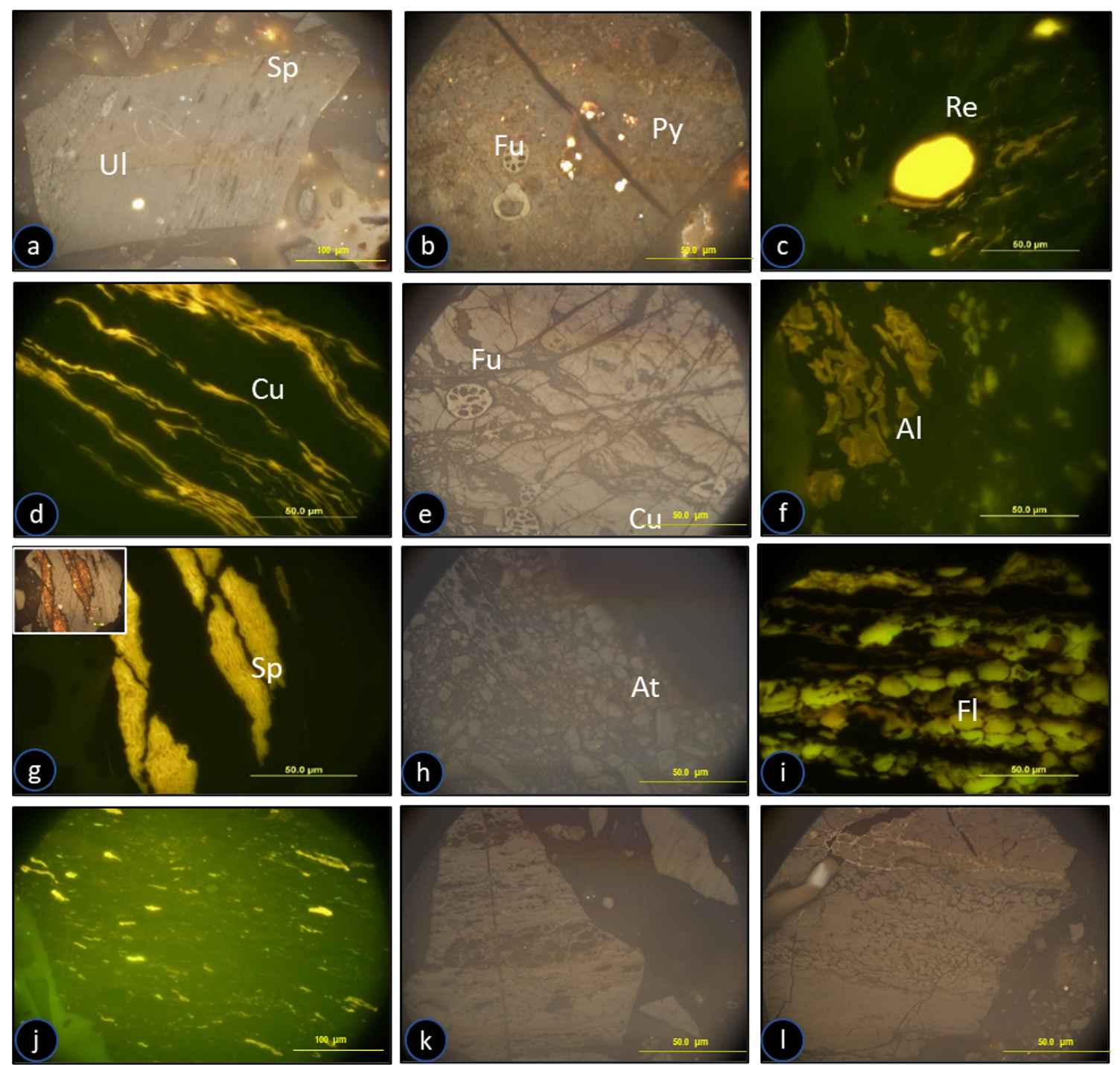

Fig. 7 Microphotographs of macerals of the San Fernando Formation. a Ulminite (Ul) bands containing microspores-tenuispores, inertodetrinite and framboidal pyrite in M305. b Textinite that envelops mineral matter (pyrite, clay) and inertinite such as funginite and inertodetrinite in M305. c Liptinites with fluorescence (resinite and sporinite) in M304. d Thin wall cutinite (fluorescence), well preserved in M304. e Ulminite bands interrupted by fractures, deformed cutinite, and sclerotinite- funginite, equally affected in M303. f Botryococcus algae colonies of planktonic origin in M302. g Microspore sporangium in M302 and M301. h Attrinite in M301. i Fluorinite under fluorescence in M301. j Microsporinite (under fluorescent light) in a ground mass of densinite in M301. k Textinite in M301. I Corpohuminite and ulminite bands in M301. Textinite (Tx), Ulminite (Ul), Densinite (De), Attrinite (At), Corpohuminite (Ch), Funginite (Fu), Inertodetrinite (Id), Sporinitesporangium (Sp), Cutinite $(\mathrm{Cu})$, Resinite $(\mathrm{Re})$, Alginite $(\mathrm{Al})$, Fluorinite $(\mathrm{Fl})$, Pyrite mineral matter (Py) 


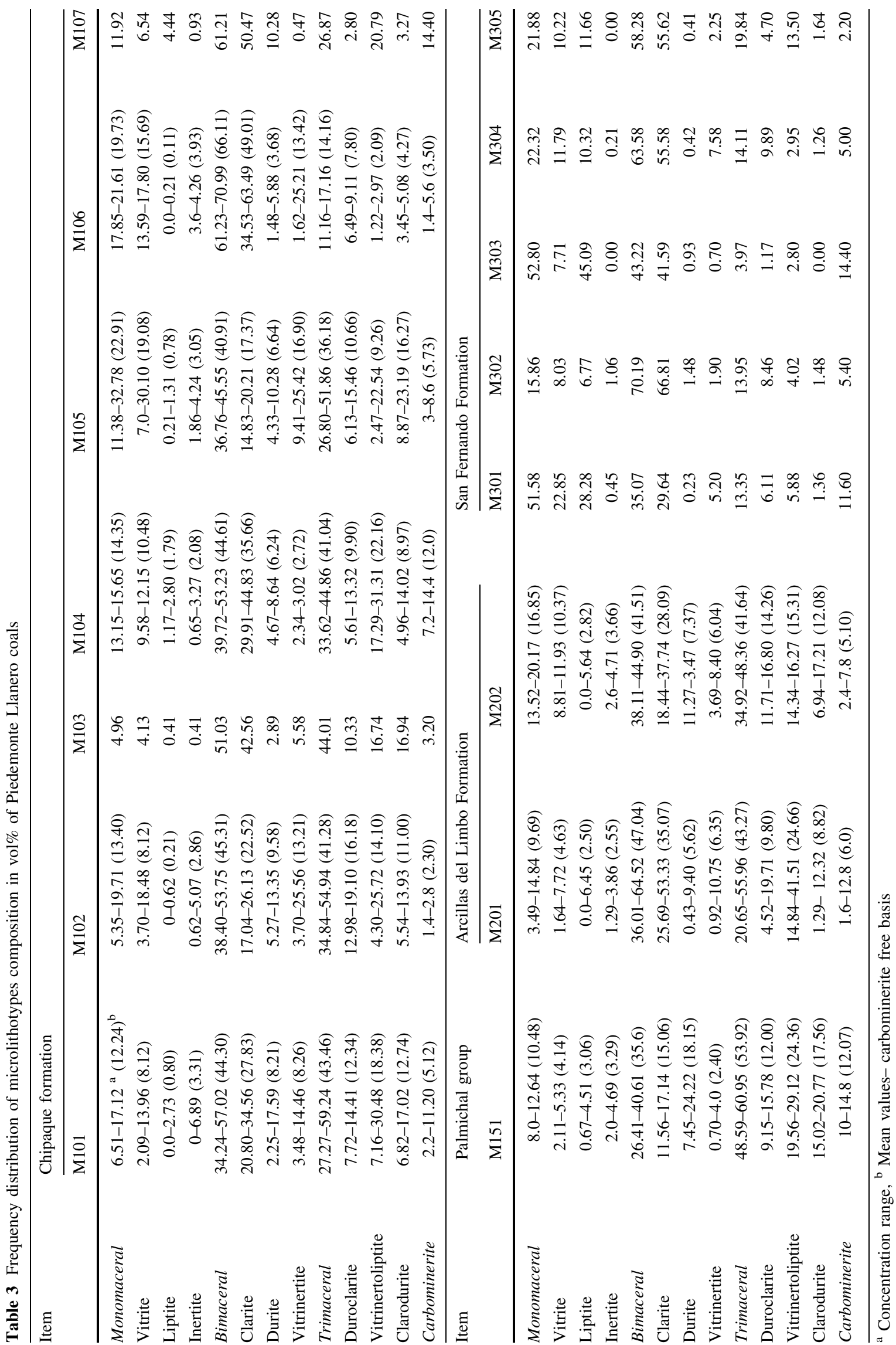



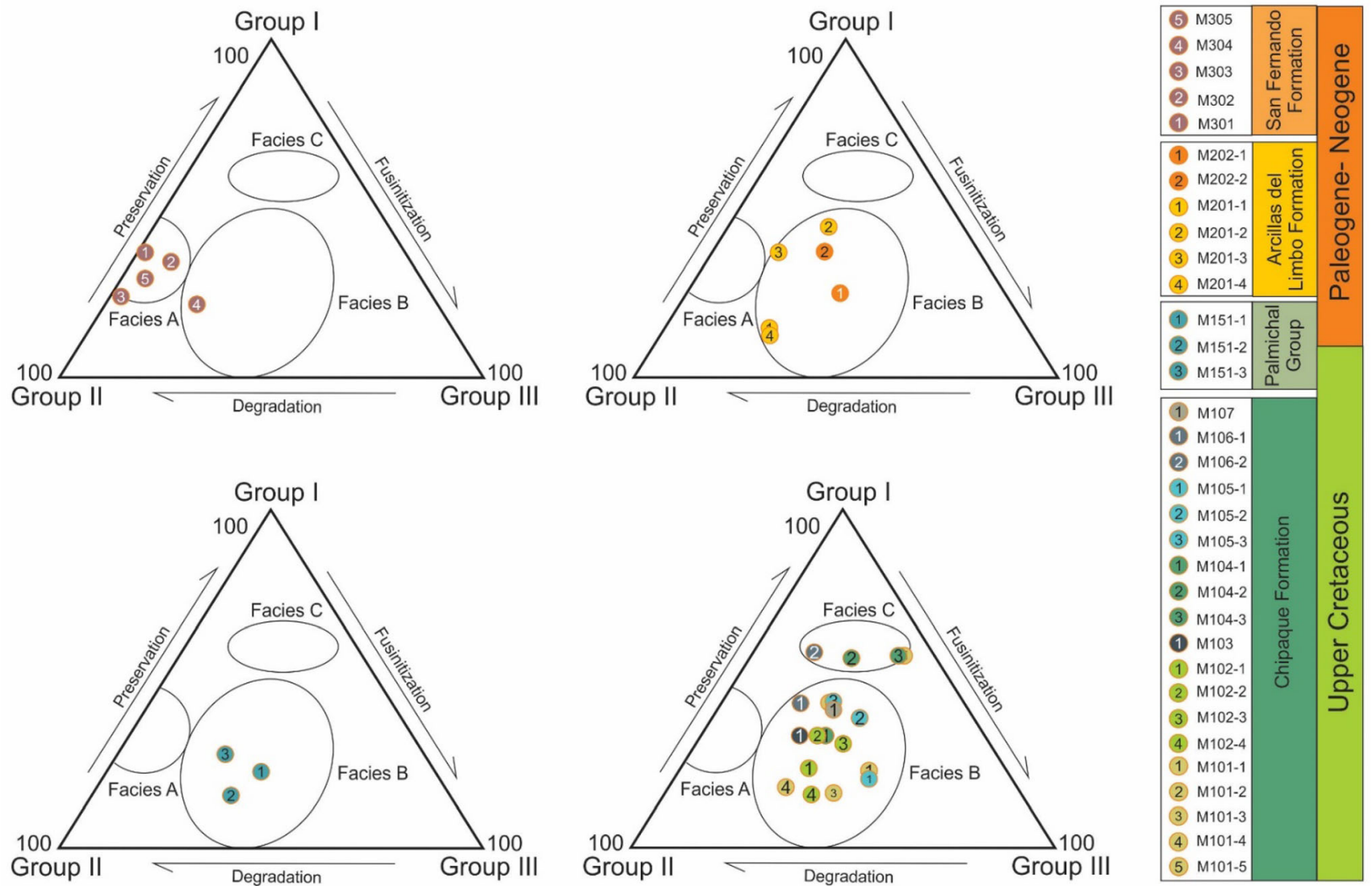

Fig. 8 Ternary diagram illustrating genetic facies of Piedemonte Llanero coals. Group I-Telovitrinite Group II-Detrovitrinite, Corpogelinite, Liptinite, Micrinite Group III Fusinite, Semifusinite, Macrinite, Inertodetrinite. Modified from Rimmer et al. (2000)

preserves macerals, the index quantifies the degree of humification suffered by the precursor macerals of the organic matter and the proportion of woody matter that contributes to the total groundmass of the peat (e.g. Singh and Singh 2000; Singh 2016).

To determine the factors that control the peatlands, Calder et al. (1991) introduced the GWI and VI indices. The Groundwater Index (GWI) deals with the ratio of the strongly gelled tissue and poorly gelled tissue, depending on the water supply and the $\mathrm{pH}$. The Vegetation Index (VI) corresponds to the contrast of macerals of forest affinity related to those of marginal herbaceous and aquatic affinity (Suárez et al. 2012).

$$
\begin{aligned}
\mathrm{GWI}= & \text { Gelinite }+ \text { corpogelinite }+ \text { clay mineral } \\
& + \text { quartz }+ \text { vitrodetrinite } / \text { telinite } \\
& + \text { collotelinite }+ \text { collodetrinite }
\end{aligned}
$$

$\mathrm{VI}=$ telinite + collotelinite + semifusinite

+ fusinite + suberinite + resinite/collodetrinite

+ inertodetrinite + alginite + liptodetrinite

+ sporinite + cutinite
The macerals gelation degree of the Piedemonte Llanero coals indicates a limnic environment (lacustrine zones) in the Chipaque, Palmichal Group and Arcillas del Limbo formations coals, and telmatic conditions for San Fernando Formation coals. The water contribution in the peat formation with scarce nutrients from precipitation according to low GWI (Calder et al. 1991) and interdigitation to rheotrophic conditions are also observed (Figs. 13, 14).

The indices values obtained in the Piedemonte Llanero coals are shown in Table 4, where TPI and VI indices reveal the preservation of vegetation tissues made up of woody plants and trees, wet forest swamps, and herbaceous vegetation $(\mathrm{VI}<3)$ similar values of Suárez et al. 2012. The TPI value between 1 and 7 is an indicator of the good preservation tissues. The Low TPI value indicates an important contribution of oxidated material vegetal (Dai et al. 2020).

The inertinite group has a high proportion in the analyzed coals, except in the San Fernando Formation. These concentrations are also observed in the results of the petrographic indices which are of importance in the interpretation of the coal formation conditions. 

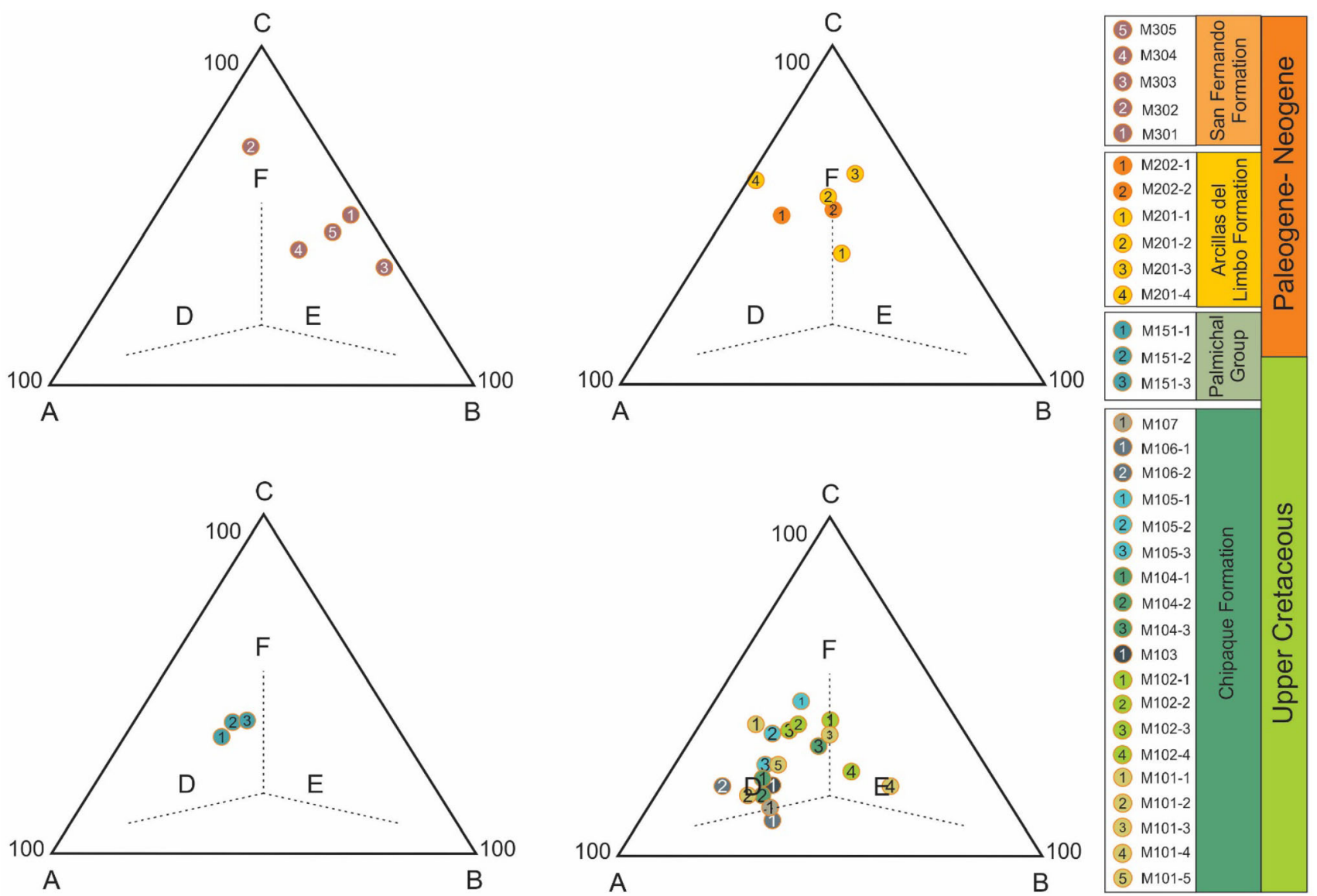

Fig. 9 The ternary diagram suggesting a peat-formation environment of Piedemonte Llanero coals (modified from Mukhopadhyay 1986). a Huminite + terrestrial liptinite. b Humodetrinite + liptodetrinite + gelinite. c Inertinite. d Forest swamp, halfway between oxic and anoxic, with good tissue preservation. e Reed marsh, with increased maceration and bacterial activity, and an anoxic increase. $\mathbf{f}$ Dry condition (oxidant)

\subsection{Deposit environment}

Smyth's $(1979,1984)$ model based on microlithotypes, defines five areas that signify different sedimentary environments: lake, river, brackish, upper deltaic, and lower deltaic. The model reflects the oxidation degree of the organic matter prior burial and the vitrinite content in order to determine the environment of coal deposition. Dai et al. 2020 indicate the importance of variations in "constructive" and "destructive" processes at the interface of environments as important considerations in the analysis and interpretation. According to Sen et al. 2016, this model does not provide the existence of ombrogenous environments, nor does it attempt to determine the vegetation types. The Piedemonte Llanero coals are vitrinite rich and located between the ombrotrophic to the mesotrophic bog zone. The vegetation type is inferred from our petrographic analysis and previous contributions from other disciplines.

We consider the microlithotypes association at the vertices of the triangular model to be correct regarding its genesis. This allows us to associate the microlithotypes results to the obtained facies in the Piedemonte Llanero coals, and to identify the differences in the deposit setting of the samples for each formation from the Upper Cretaceous to Middle Miocene age. However, we consider that the areas delimited by Smith $(1979,1984)$ can be modified in the upper delta plain to identify more transitional subenvironments (Fig. 15).

The Durita + Inertite association indicates greater oxidation of the organic matter of the Arcillas del Limbo Formation, where the low water table level is associated to dry peat (Diessel 1992). Vitrita + Clarite show greater subsidence, and the preservation of the tissue in the San Fernando Formation. The so-called intermediate microlithotypes are the indicative to local fires or major transport, and high energy in the coal units.

The Piedemonte Llanero coals reflect variations in the humidity conditions, oxidation, and the influence of the brackish water. The petrography results, together with previous studies of stratigraphy, and palynology, allow us to deduce the evolution from an estuarine to a deltaic system-lacustrine (Fig. 15). The preservation processes of peat, or the estuarine environment that allowed the development of the coals, follow the definition of estuary given 

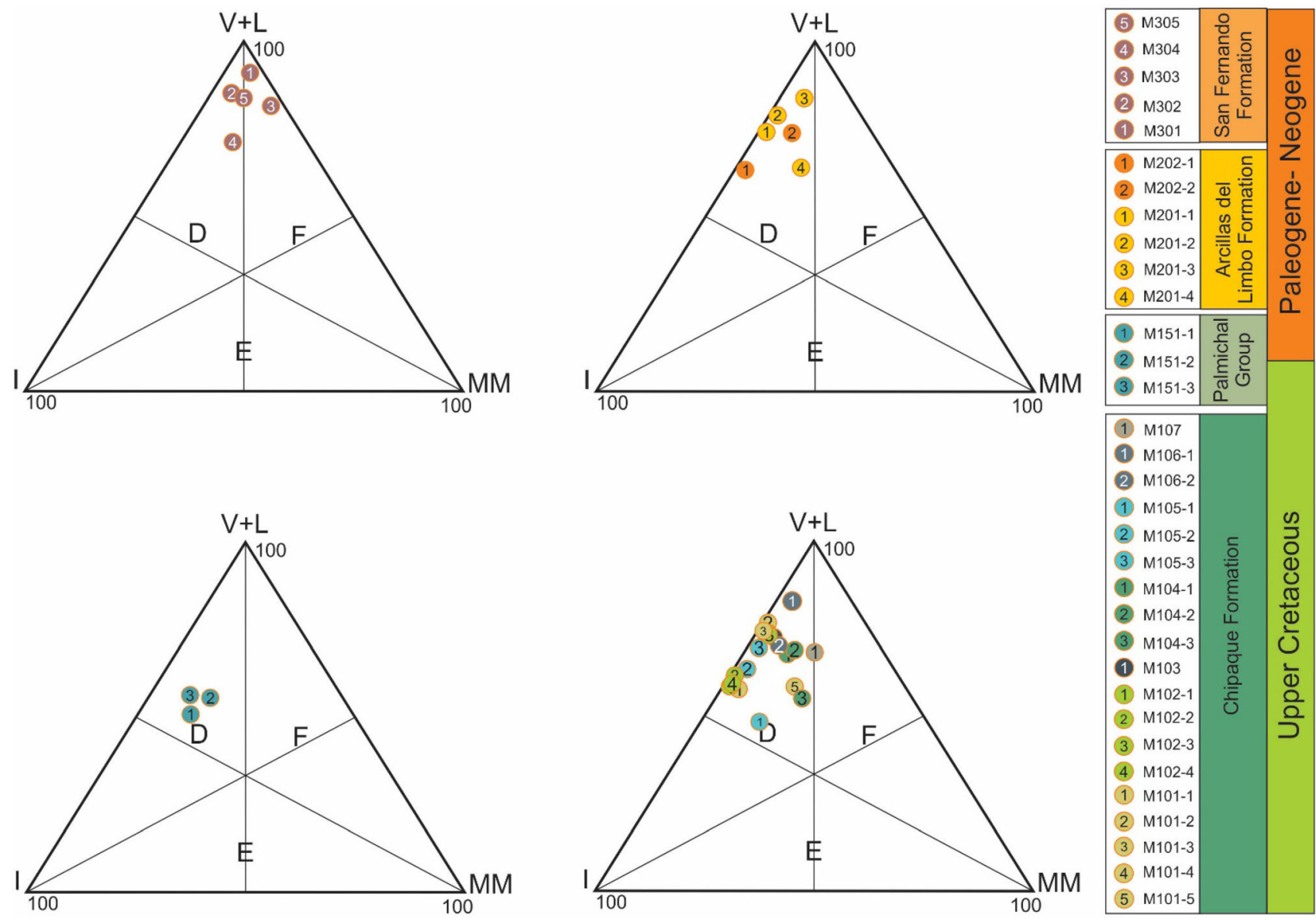

Fig. 10 Ternary diagram suggesting coal facies of Piedemonte Llanero coals (Singh and Singh, 1996). D. Alternate oxic and anoxic moor. E. Oxic (dry) moor with sudden high flooding. F. Wet moor with intermittent moderate to high flooding

by Dalrymple et al. 1992. According to these authors, the term is supported in sedimentological criteria and defined as "the portion towards the sea of a flooded river system that receives sediment from river and marine source areas and contains sedimentary facies influenced by tides, waves and river processes“.

\subsubsection{Chipaque formation (late cenomanian-santonian)}

Coal petrology indicates low oxidation conditions as shown by the low percentages of durite and inertite microlithotypes, and significant contents of vitrite and clarite microlithotypes that indicate humid environments. Guerrero and Sarmiento (1996) indicate an estuarine environment and micro-tidal dominated by waves according to the stratigraphy and palynology study of a mixture of Dinoflagellates and pollen in the lower segment of the formation (Fig. 16). The coals developed in a partially closed lagoon, which it is corroborated by the increase in the content of detrovitrinite and oxidized vitrinite that indicates a $\mathrm{pH}$ increase due to the incursion of marine waters and the degradation in the tissues. The Inertinite percentage reflects the alternation of wet and dry periods with water oxygenated under the tidal influence (Diessel 1992). The low oxidation and good preservation of the macerals are corroborated by deposition that occurs in extensional basins with half-graben geometry (post-rift). The accommodation space generated the subsequent deposition of marine facies and the beginning of a transgressive event (Guerrero and Sarmiento 1996; Horton et al. 2020).

\subsubsection{The palmichal group (early campanian- maastrichtian)}

The coals of this unit show a medium degree of oxidation with a moderate concentration of the vitrinitic, inertinitic, and liptinitic micro-lithotypes. Botryococcus colonies are indicative of swamp environments, periods of the shallow watershed, and the climate variations (Diessel 1992), and the high concentrations of inertinite indicate periods of greater oxidation. The coals were deposited in shallow bays, swamps, and coastal lagoons of an estuarine system (the Guaduas Formation in Guerrero and Sarmiento 1996; 


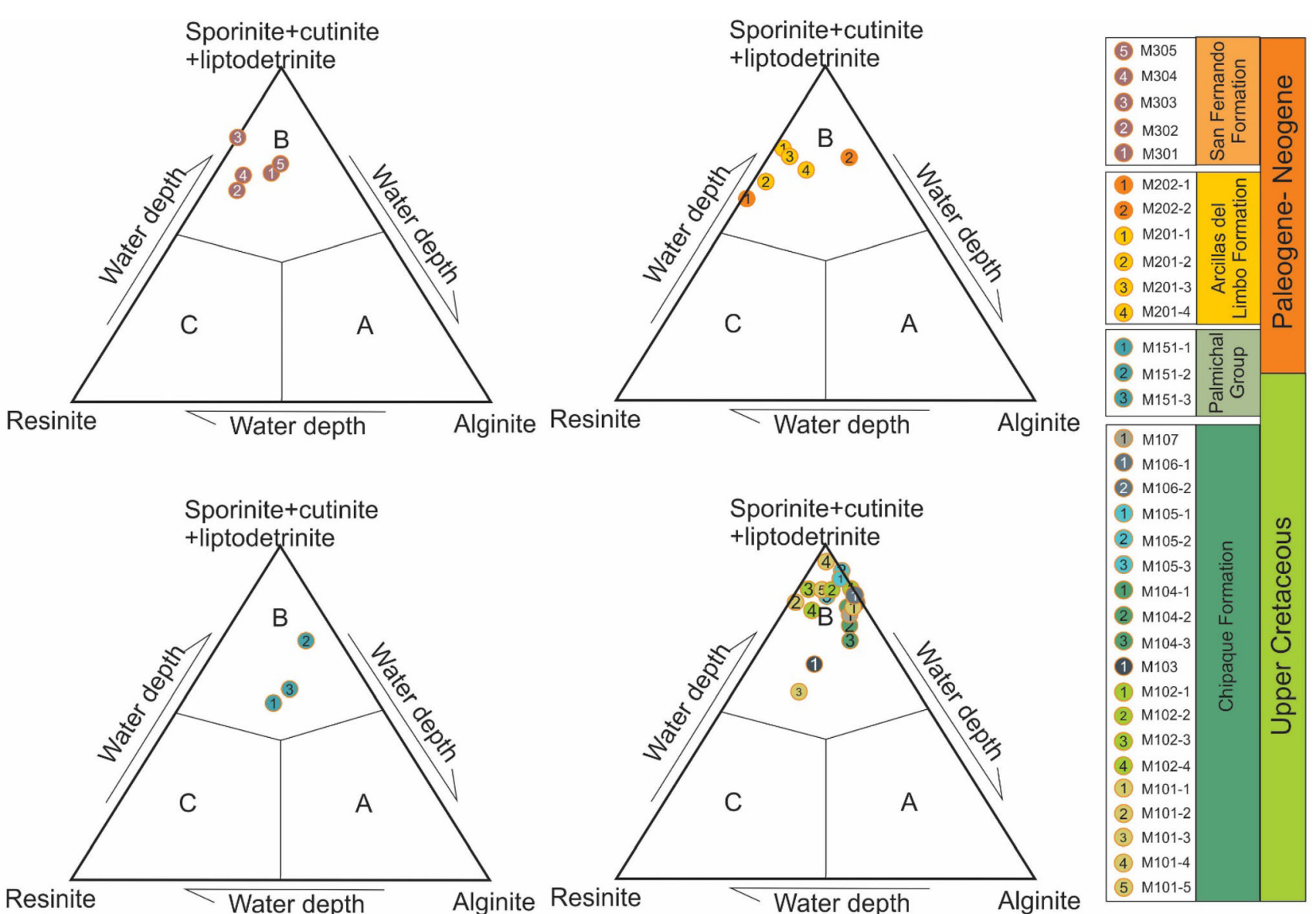

Fig. 11 Ternary diagrams for facies models controlled by water depth conditions of peat swamp of the Piedemonte Llanero coals (modified from Singh and Singh 2000) a Area for the development of algal bloom and the zone of anaerobic bacterial activity. b Open-water swamp dominated by reed plants. c Transition between forest swamp and reed swamp

Ulloa 1976a, Fig. 16), along an open lagoon with tidal and wave processes active, possibly. In the regional geological framework, the oxidation periods are related to the initial pulse of the Colombian Andes uplift (Central Cordillera), with the first great crust shortening and the foreland basin formation as the evidence (Horton et al. 2020). For this reason, tectonics controlled the sedimentation, the accommodation space decreased, and shallow coastal marine environments developed (Villamil 1999).

\subsubsection{Arcillas del limbo formation-late paleocene}

The coals show the highest-level oxidation in the studied sequence. According to Guerrero and Sarmiento 1996, the coals were deposited in a lagoon of estuarine coastal plain environment (from pollen and spores studies Fig. 16). The content of intermediate micro-lithotypes is low, as to indicate a freshwater deposit and low salty water influence. The monomaceral and bimaceral micro-lithotypes proportion is considerable, mainly composed of durite and inertite due to the important inertinite concentration. The inertodetrinite indicates high oxidation and desiccation of the peat, caused by an intermittent drop in the local water table, the cutinite and sporinite have thick-walled protect against dehydration, indicating dry environments (Diessel 1992). The dry period with greater oxidation in coals is a consequence of accommodation space, which decreases due to the crust uplift as result of the initial phase of tectonic inversion from prior normal faults, and shallowcoastal environments are developed (Villamil 1999).

\subsubsection{San Fernando formation (late eocene-early Miocene)}

The coals reflect a higher concentration of vitrite and clarite as a product of wooded peat bogs and low oxidation under telmatic conditions. The spores and cutinite are very well preserved with a thin wall, which indicates the humid environments of terrestrial plants. The low oxygen concentration in the environment favored the preservation of plant tissues in a lacustrine setting. Some brackish incursions are suggested in previous studies (Dueñas and van der 

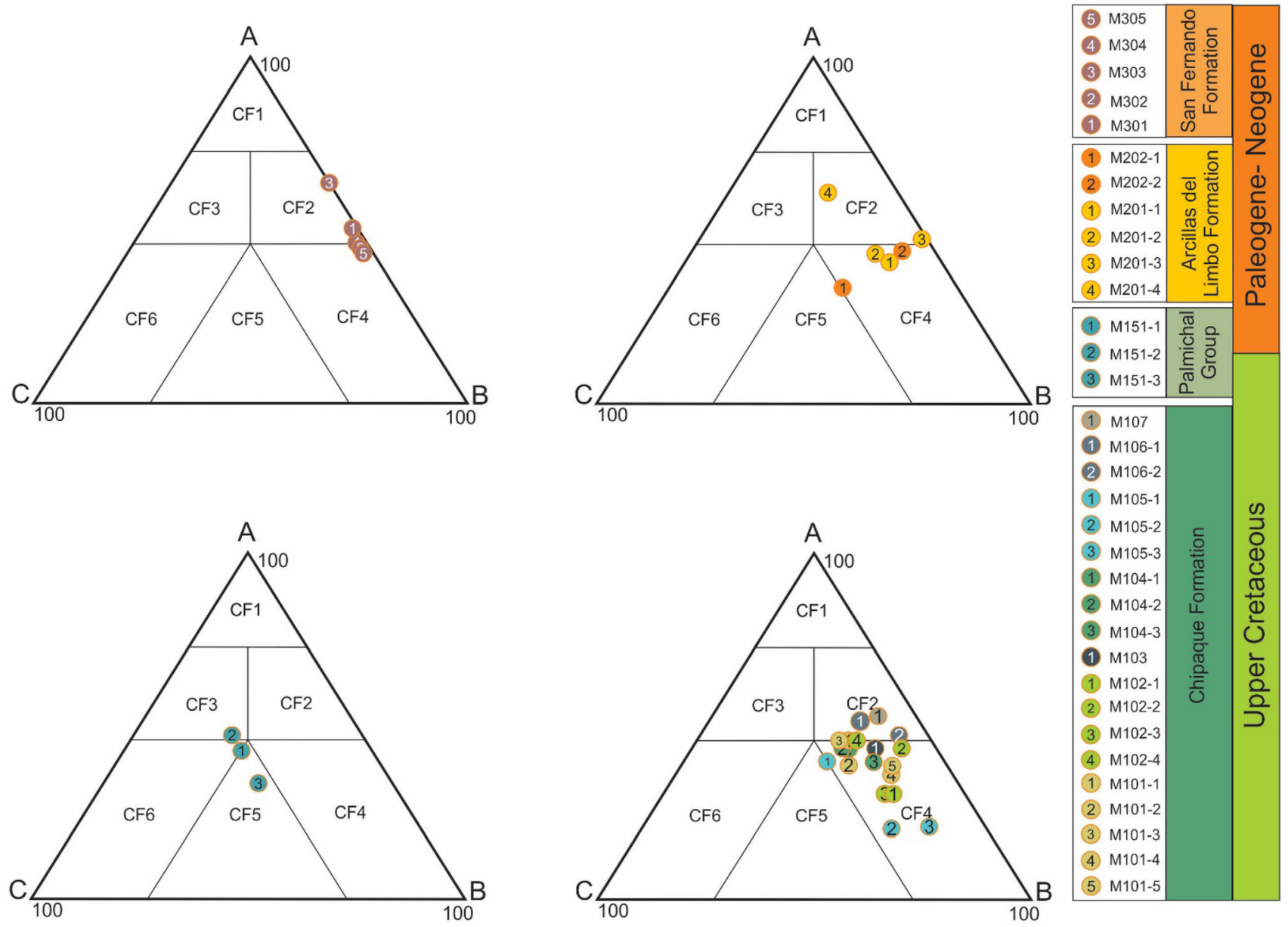

Fig. 12 Ternary diagram for coal facies of the Piedemonte Llanero coals. (modified from Singh et al. 2013). a=liptite + clarite $(\mathrm{L})+$ vitrinertoliptite + durite $(\mathrm{L}), \mathbf{b}=$ vitrite + clarite $(\mathrm{V})+$ vitrinertite $(\mathrm{V})+$ duroclarite, $\mathbf{c}=$ inertite + durite $(\mathrm{I})+$ clarodurite + vitrinertite (I). The types of facies delineated are CF1, deep-water facies, characterized by organic mud, rich in liptinites. CF2, open water with dominance of subaquatic plants. CF3, forest swamp with sudden eustatic changes. CF4, forest to reed swamp. CF5, forest swamp. CF6, moss swamp with extremely dry conditions

Hammen 2007; Parra et al. 2008; Caballero et al. 2020, Fig. 16), related to the intermediate microlithotypes content and sulfides in framboidal shape. The low oxidation of the organic matter in this period is related to the accommodation space increases, as a result of the subsidence of the basin and a transgressive event that allows the entry of marginal marine systems (Villamil 1999).

\subsection{Paleovegetation}

Previous palynological studies reveal the dominance of angiosperms in the Upper Cretaceous (Guerrero and Sarmiento 1996) up to Lower Eocene (Pardo and Jaramillo 2014). For the Chipaque Formation, Plamichal Group, and the Arcillas del Limbo Formation, the petrology analysis reveals a transition from forest swamps to reed swamps, characterized by short trees, shrubs, and herbaceous vegetation, since they develop mainly in bogs.
In the middle Eocene period, Pardo and Jaramillo (2014) registered the spore domain of the Pteridophytes. This time interval includes the lower segment of the San Fernando Formation. Petrographically, it is evidenced with a high percentage of thin-walled sporinite and sporangium, low content of inerts, and mono-bimaceral microlithotypes (Vitrite, Liptite, Clarite). In the intermediate segment of the San Fernando Formation, Pardo and Jaramillo (2014) report mangrove vegetation, which may be related to M304 and M305, where sporangium is no longer evident and sporinite-microsporinite is abundant (Fig. 16).

Our results procured from petrographic, facies and paleoenvironment identification are like to those obtained in other countries (e.g. German, Australian, Polish, Canadian, North America, Spain, India, China, Brasil). Singh and Singh (2000) studied Eocene coals of platform basins (Meghalaya, India) and indicate lagoon and estuarine environments subject to recurrent transgressions and 

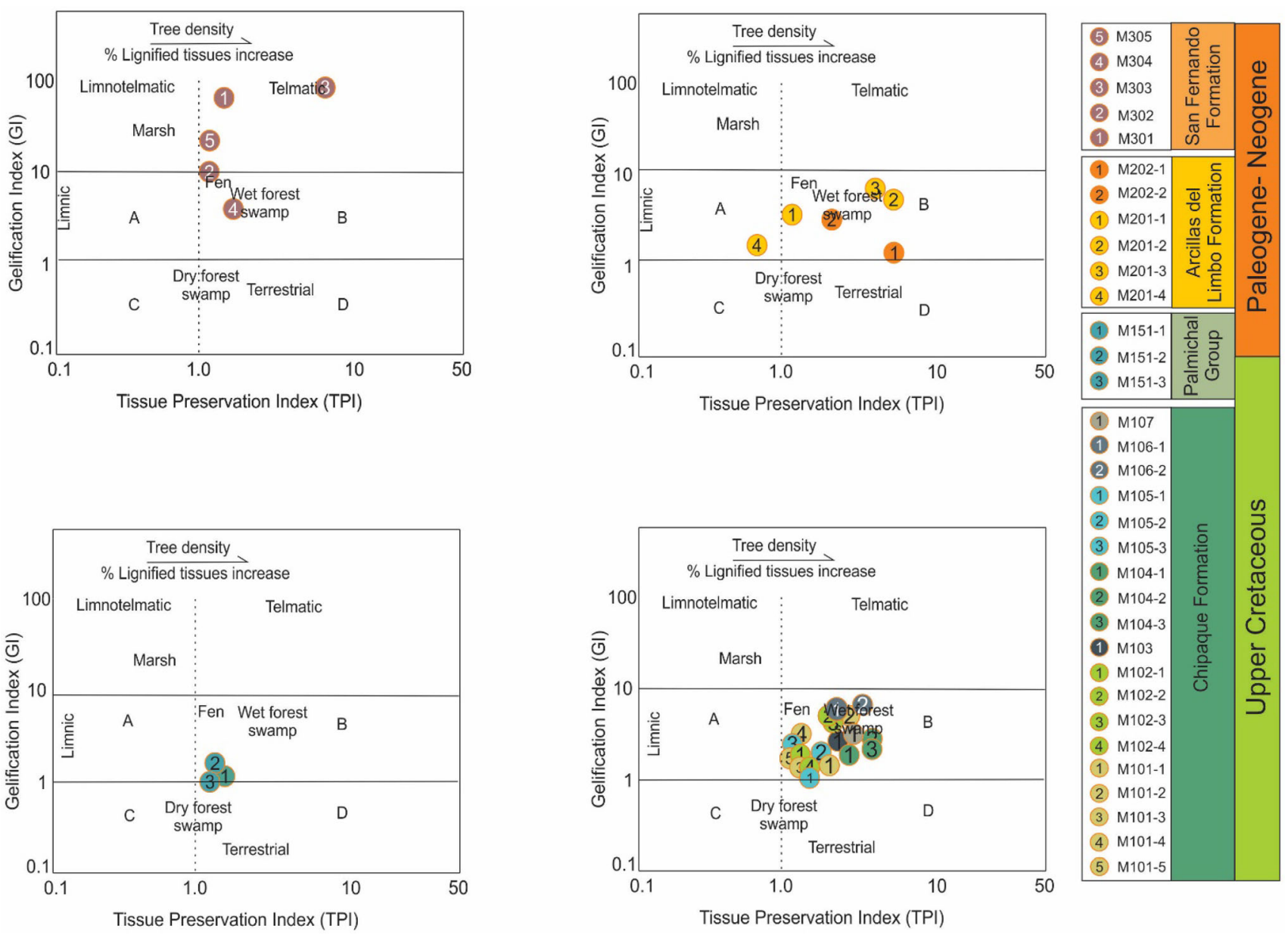

Fig. 13 Coal facies obtained from GI and TPI indices related to depositional setting, and type of mire of Piedemonte Llanero coals (after Diessel 1986 and modified by Kalkreuth et al. 1991). A. Vitrinite $>$ Inertinite, Degraded vitrinite $>$ structured vitrinite B. Vitrinite $>$ Inertinite, Structured vitrinite $>$ Degraded vitrinite C. Inertinite $>$ Vitrinite Inertodetrinite $>$ semifusinite + fusinite D. Inertinite $>$ Vitrinite, Semifusinite + fusinite $>$ Inertodetrinite

regressions; Singh et al. 2013, researched Oligocene coals from the foreland basin of northeast India, where they identified tertiary flora and the occurrence of inertinite macerals related to tectonic upheavals; Singh 2016, studied the Karharbari (Lower Permian) coals, India, concluding that the accumulation of peat in forest mud is affected by oxic to anoxic fluctuating conditions with good tissue preservation; and Feng et al. 2019 developed the study in the district of Hanshuiquan, Santanghu Coalfield, Xinjiang, NW China, in the Middle Jurassic coals, indicating wet forest swamp facies with a high value of TPI and VI, low GI and GWI, and high inertinite content in the maceral composition, as occurs in the Piedemonte Llanero coals.

From these issues, we consider that the basic concepts of peat formation can be applied in any place and age of the geological context, considering the evolution of each particular basin.

\subsection{Coal petrology application}

The coal petrology is an indicator of the organic matter type, range, distribution, lateral continuity, thickness, and organic and mineral composition, which can support research in several applied topics. Although our research does not have such scope, we mention here some potential approaches for future studies.

\subsubsection{Basin analysis}

The coal petrology in basin analysis contributes to the organic facies understanding. The coal facies are important to deduce the accumulation and subsidence rates of the basin, to define the depositional systems, and to infer the sedimentary processes in the analysis of stratigraphic sequences, and the thermal history evaluation (e.g. Diessel 1992, 2007; Qiu et al. 2011; Suarez et al. 2012; Singh and Singh 2013). 

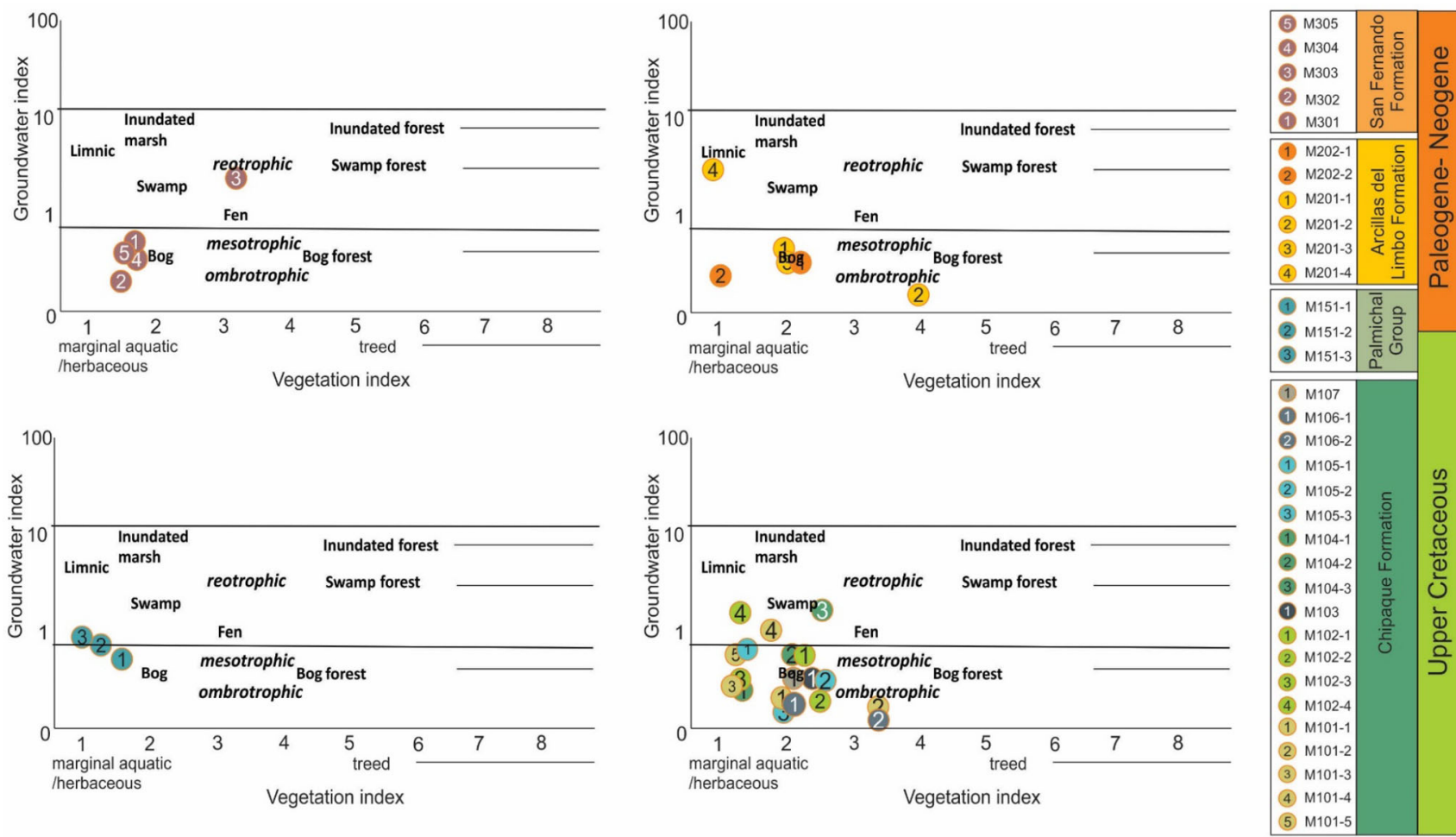

Fig. 14 Mire paleoenvironmental diagram from GW and VI indices of Piedemonte Llanero coals (modified after Calder et al. 1991)

Table 4 Petrographic indices of the Piedemonte Llanero coals in the Eastern Cordillera of Colombia

\begin{tabular}{lllll}
\hline Formation & GI & TPI & VI & GWI \\
\hline $\begin{array}{l}\text { San Fernando } \\
\quad \text { Formation }\end{array}$ & $3.28-86.50$ & $1.38-6.69$ & $1.41-3.19$ & $0.27-2.53$ \\
$\begin{array}{c}\text { Arcillas del Limbo } \\
\quad \text { Formation }\end{array}$ & $1.28-5.53$ & $0.76-4.11$ & $0.66-3.95$ & $0.25-2.52$ \\
$\begin{array}{l}\text { Palmichal group } \\
\text { Chipaque }\end{array}$ & $1.09-1.76$ & $1.58-1.96$ & $1.04-1.66$ & $0.79-1.19$ \\
$\quad$ formation & $1.14-6.69$ & $1.11-4.58$ & $1.16-3.42$ & $0.26-1.85$ \\
\hline
\end{tabular}

\subsubsection{CBM}

The coal sedimentary environment is important in areas with scarce or without exploration studies, understanding of the depositional environment allow to infer the enrichment of CBM (Hou et al. 2019). As an unconventional reservoir, the coal acts as source and reservoir rock. As source rock, it is of vital importance to define the type and degree of maturation of the organic matter, which is related to the range and content of organic components that generate hydrocarbons. The coal range and the burial depth play a significant role in the adsorption capacity of the methane gas and in the maceral composition (e.g. Laxminarayana and Crosdale 1993; Bustin and Bustin 2016; Li et al. 2016; Hou et al. 2019; Zhao et al. 2019; Busch et al. 2019), as well as defining the quality of the coal deposit (Farhaduzzaman et al. 2012; Miao 2016 in Hou et al. 2019). Also, according to the deposit environment, it allows the evaluation of the seal conditions of the adjacent rocks (Li et al. 2014).

\subsubsection{Rare earth exploration}

In recent decades, the rare earth elements occurrence (REE and REY) in coal and coal ash has been studied according to the economic interest, and Colombia is not an exception. Rare earth elements in coal can be found in organic or mineral associations or dissolved in water in pores in lowranking coals (Dai 2020). The coal environment allows a link to the identification of REY, according to the occurrence mode, abundance, and origin, as well as in the definition of the associated mechanisms and the enrichment mode when determining anomalies (Dai 2020; Finkelman 2019; Hower 2016; Seredin 2012).

\section{Conclusions}

The coal formation in the Piedemonte Llanero sequence (Late Cretaceous to Early Miocene) was interpreted from the petrological analysis. The evolution of an estuarine 


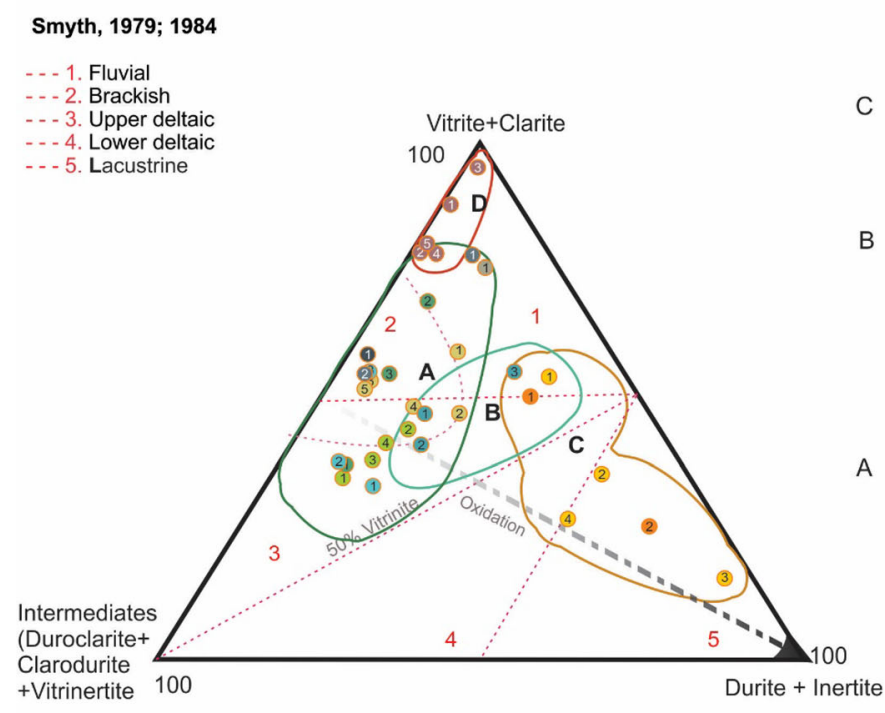

Estuarine system

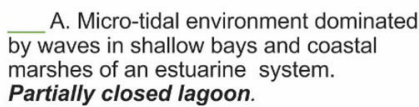

A. Micro-tidal environment dominat
by waves in shallow bays and coastal
marshes of an estuarine system. Partially closed lagoon.
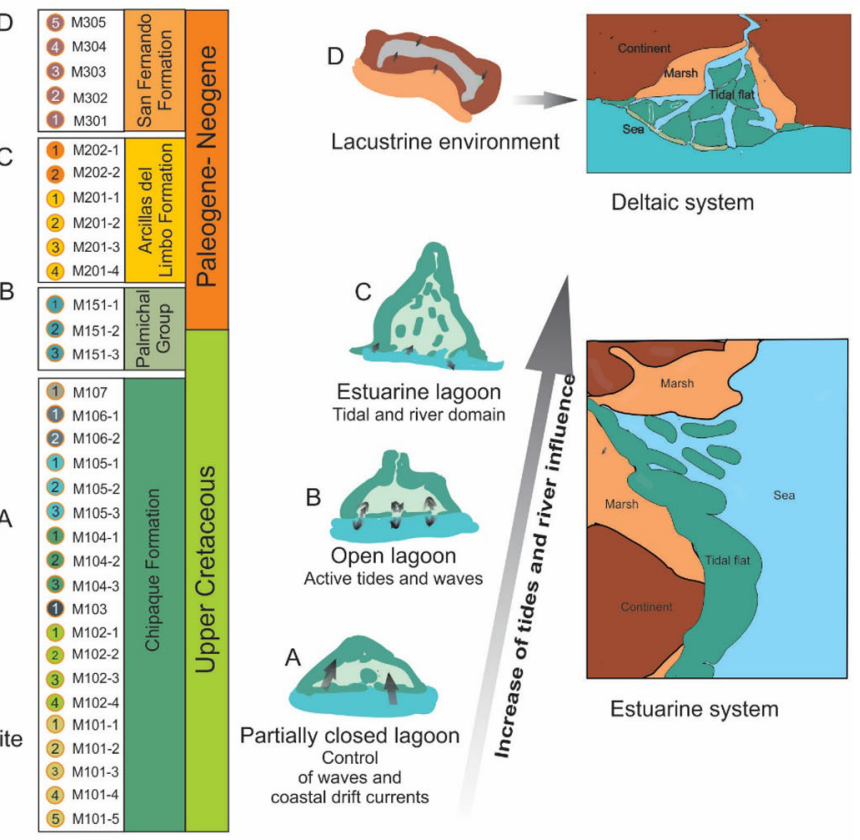

Fig. 15 Microlithotypes ternary diagram of the Piedemonte Llanero coals showing the evolution of an estuarine to deltaic system (adapted from Smyth 1979, 1984)

system was determined, which ends in a lacustrine-telmatic environment with the entry of marginal marine systems.

The tectonic events that occurred in the Piedemonte Llanero basin were transcendent in the accommodation space and the coal facies development. Such variations are inferred from the water level covering the peat and the humification degree of the organic matter, marking lower or greater oxidation periods from the post-rift basin to the foreland basin.
The microscopic constituents of the Piedemonte Llanero coals indicate peat accumulation in the wet forest swamps with arboreal and herbaceous affinity, under fluctuating of oxic to anoxic conditions with good tissue preservation.

The interdisciplinary work with stratigraphy and palynology plays an important role in the robust interpretation of facies, deposit environment, and the identification of the petrographic characteristics of the vegetation. 


\begin{tabular}{|c|c|c|c|c|c|c|}
\hline \multirow[t]{2}{*}{ 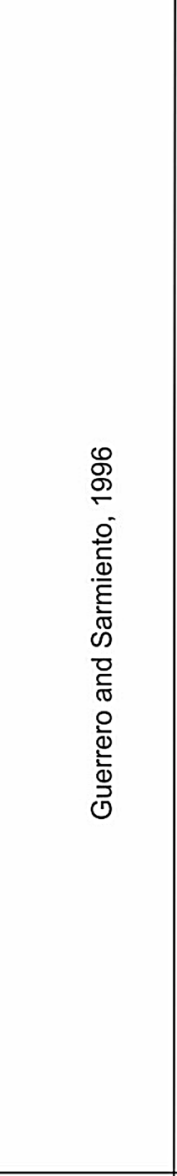 } & \multicolumn{5}{|c|}{ 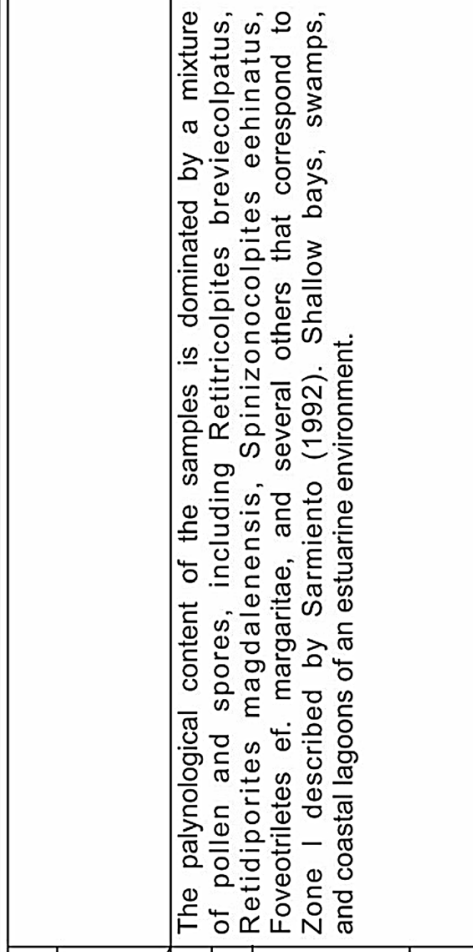 } & \multirow[t]{2}{*}{ 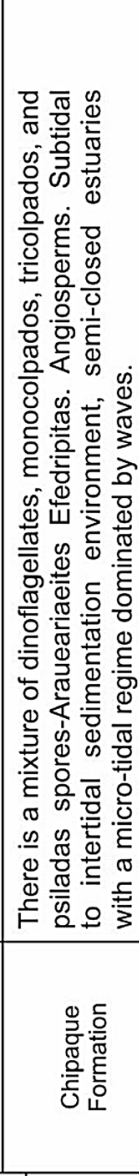 } \\
\hline & 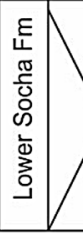 & & 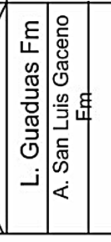 & 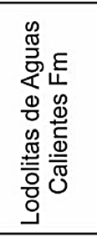 & 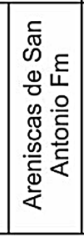 & \\
\hline $\begin{array}{l}0 \\
\frac{1}{0} \\
\infty \\
\frac{0}{5}\end{array}$ & 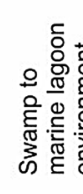 & \multicolumn{4}{|c|}{ 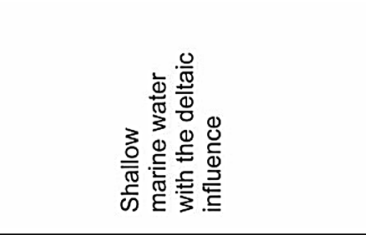 } & 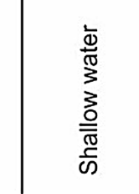 \\
\hline 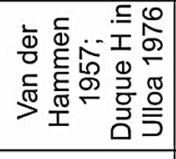 & 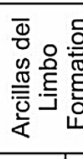 & \multicolumn{4}{|c|}{ 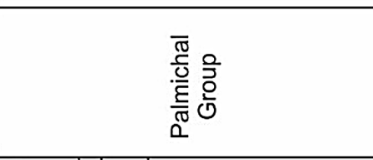 } & 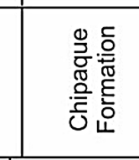 \\
\hline 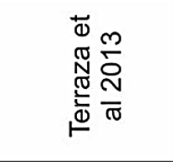 & 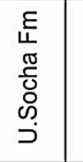 & 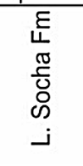 & 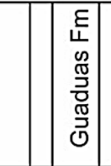 & 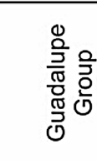 & & 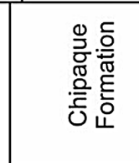 \\
\hline 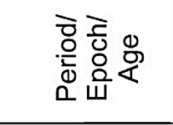 & $\begin{array}{l}0 \\
\frac{8}{\sigma 0} \\
\frac{0}{\sigma 0} \\
د\end{array}$ & 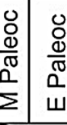 & \multicolumn{4}{|c|}{ 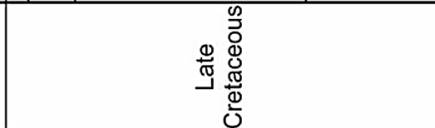 } \\
\hline$\sum^{\pi}$ & & $\begin{array}{l}8 \\
\dot{8} \\
\end{array}$ & : & & $\begin{array}{l}8 \\
\dot{\infty} \\
\infty\end{array}$ & \\
\hline
\end{tabular}




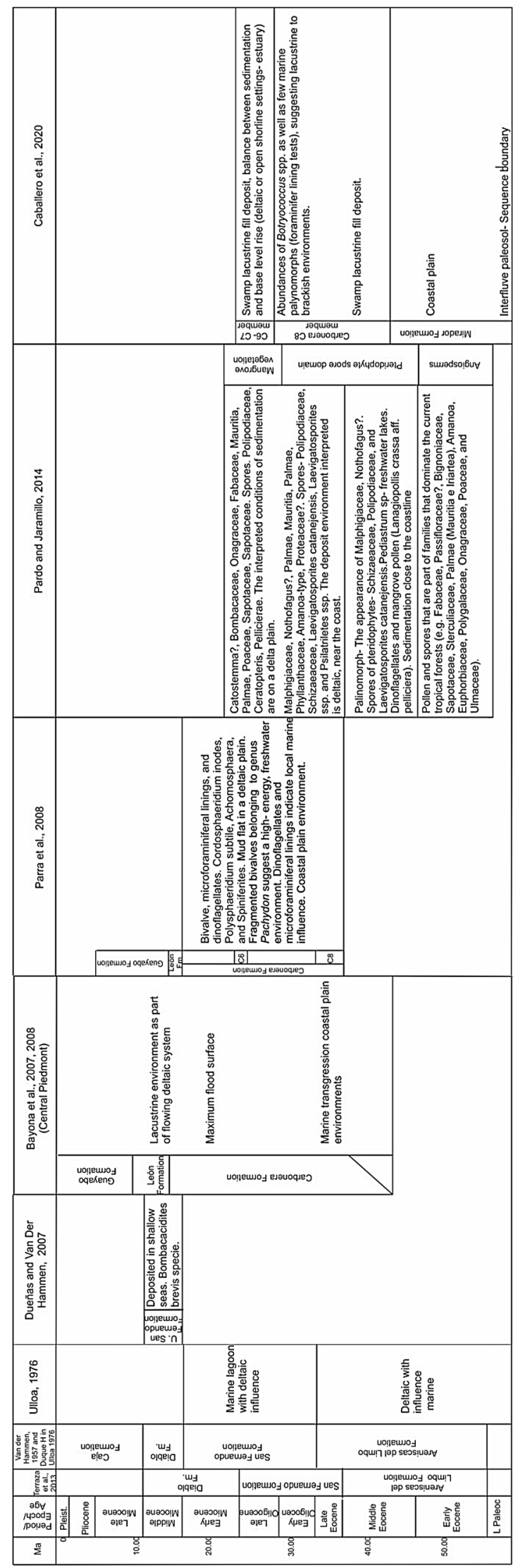

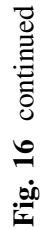


Coal petrology offers significant data for the exploration of new use alternatives, from the composition, range, facies, and deposit environment.

Acknowledgements The authors would like to thank the geologists William Monroy, Robinson Patiño, and Manuel Sandoval of the Servicio Geológico Colombiano for the detailed work of geological cartography, the description, sampling, and characterization of the coal seams. We are grateful to the professional group of the Chemical Laboratory (part of the Servicio Geológico Colombiano) for the chemical analysis. To the Director of Mineral Resources of the Servicio Geológico Colombiano, Ph.D. Gloria Prieto, for support and believing in this research topic as a fundamental tool in the studies of the Research and Exploration of Energy Mineral Resources.

Funding This research is part of the Exploration in Energy Resources Project of the Servicio Geológico Colombiano.

\section{Availability of data and materials Applicable.}

Code availability Not applicable.

\section{Compliance with ethical standards}

Conflict of interest The authors declare that they have no conflict of interest.

Open Access This article is licensed under a Creative Commons Attribution 4.0 International License, which permits use, sharing, adaptation, distribution and reproduction in any medium or format, as long as you give appropriate credit to the original author(s) and the source, provide a link to the Creative Commons licence, and indicate if changes were made. The images or other third party material in this article are included in the article's Creative Commons licence, unless indicated otherwise in a credit line to the material. If material is not included in the article's Creative Commons licence and your intended use is not permitted by statutory regulation or exceeds the permitted use, you will need to obtain permission directly from the copyright holder. To view a copy of this licence, visit http://creativecommons. org/licenses/by/4.0/.

\section{References}

ASTM (1999) D388-99 Standardclassification of coals by rank. ASTM Philadelphia

ASTM (2005a) D2799-05 Standard test method for microscopical determination of the maceral composition of coal. ASTM Philadelphia

ASTM (2005b) D2798-05 Standard test method for microscopical determination of the vitrinite reflectance of coal. ASTM Philadelphia

ASTM (2004) D2797-04 Standard practice for preparing coal samples for microscopical analysis by reflected light. ASTM West Conshohocken

Barrero D, Pardo A. Vargas C, Martínez J (2007) Colombian sedimentary basins: nomenclature, boundaries and petroleum geology, a new proposal. ANH Colombia

Bayona G, Jaramillo C, Rueda M, Reyes H, Torres V (2007) Paleocene-middle Miocene flexural-margin migration of the nonmarine llanos foreland basin of Colombia. Ciencia Tecnología y Futuro 3(3):51-70

Bayona G, Valencia A, Mora A et al (2008) Estratigrafía y procedencia de las rocas del Mioceno en la parte distal de la cuenca antepais de los Llanos de Colombia. Geol Colomb 33:23-46

Bechtel A, Karayiğit AI, Sachsenhofer RF et al (2014) Spatial and temporal variability in vegetation and coal facies as reflected by organic petrological and geochemical data in the Middle Miocene Çayirhan coal field (Turkey). Int J Coal Geol 134-135:46-60. https://doi.org/10.1016/j.coal.2014.09.011

Blandón A (2007) Contribución de la materia orgánica sedimentaria a la determinación del paleoambiente y del potencial de generación de hidrocarburos en los carbones de la Formación Amagá (Colombia). Thèse de doctorat: Univ. Genève 2006 no. Sc. 3806

Boggs S (1987) Principles of sedimentology and stratigraphy. Macmillan, N.Y.

Boyd R, Dalrymple R, Zaitlin BA (1992) Classification of clastic coastal depositional environments. Sedimen Geol 80:139-150. https://doi.org/10.1016/0037-0738(92)90037-R

BP (2019) BP statistical review of world energy June 2019 68th edition. BP plc London. https://www.bp.com/content/dam/bp/ business-sites/en/global/corporate/pdfs/energy-economics/statisti cal-review/bp-stats-review-2019-full-report.pdf

Busch A, Han F, Magill CR (2019) Paleofloral dependence of coal methane sorption capacity. Int J Coal Geol. https://doi.org/10. 1016/j.coal.2019.103232

Bustin AMM, Bustin RM (2016) Total gas-in-place, gas composition and reservoir properties of coal of the Mannville coal measures, Central Alberta. Int J Coal Geol 153:127-143. https://doi.org/10. 1016/j.coal.2015.11.011

Caballero VM, Rodríguez G, Naranjo JF, Mora A, De La Parra F (2020) From facies analysis stratigraphic surfaces and depositional sequences to stratigraphic traps in the Eocene - Oligocene record of the southern Llanos and northern Magdalena Basin. In: Gómez J. and Mateus-Zabala D (eds) The Geology of Colombia, Bogotá, Volume 3 Paleogene - Neogene. Servicio Geológico Colombiano Pub Geo Esp 37, 48 p. https://doi.org/10.32685/pub. esp.37.2019.10

Calder JH, Gibling MR, Mukhopadhyay PK (1991) Peat formation in a Westphalian B piedmont setting, Cumberland Basin, Nova Scotia: implications for the maceral-based interpretation of rheotrophic and raised paleomires. Bull - Soc Geol Fr 162:283-298

Calder JH (1993) The evolution of a ground-water-influenced (Westphalian B) peat-forming ecosystem in a piedmont setting: The No.3 seam Springhill coalfield Cumberland Basin Nova Scotia. In: Cobb J.C. and Cecil C.B. (Eds.). Modern and Ancient Coal-Forming Environments. Geol Soc Am. Spec Pap 286:153-180

Castaño L, Gómez O (2001) Caracterización, origen, evolución y potencial de utilización de los carbones de la Secuencia Volcanoclástica de Aranzazu Caldas. Universidad de Caldas, Thesis

Crosdale PJ (1993) Coal maceral ratios as indicators of environment of deposition: do they work for ombrogenous mires? An example from the Miocene of New Zealand. Org Geochem 20:797-809. https://doi.org/10.1016/0146-6380(93)90064-I

Dai S, Bechtel A, Eble CF et al (2020) Recognition of peat depositional environments in coal: a review. Int $\mathrm{J}$ Coal Geol 219:103383. https://doi.org/10.1016/j.coal.2019.103383

Dalrymple RW, Zaitlin BA, Boyd R (1992) Estuarine facies models: conceptual basis and stratigraphic implications. J Sediment Res 62(6):1130-1146. https://doi.org/10.1306/D4267A69-2B2611D7-8648000102C1865D

Dehmer J (1995) Petrological and organic geochemical investigation of recent peats with known environments of deposition. Int $\mathbf{J}$ Coal Geol 28:111-138. https://doi.org/10.1016/01665162(95)00016-X 
Van der Hammen (1958) Estratigrafía del Terciario y del Maestrichtiano y tectogénesis de los Andes Colombianos. Ministerio de Minas y Petróleo, Servicio Geológico Nacional, Bogotá

Van der Hammen (1960) Estratigrafía del Terciario y del Maestrichtiano y tectogénesis de los Andes Colombianos. Ministerio de Minas y Petróleo, Servicio Geológico Nacional, Bogotá

Diessel CFK (1985) Macerals as coal facies indicators. In: Compte rendu tenth international congress for carboniferous stratigraphy and geology madrid Spain 3:367-373

Diessel CFK (1986) On the correlation between coal facies and depositional environments. In: Proceeding of 20th symposium Department of Geology. University Newcastle NSW, pp. 19-22

Diessel CFK (1992) Coal-bearing Depositional Systems. SpringerVerlag, New York Berlin, DOI. https://doi.org/10.1007/978-3642-75668-9

Diessel CFK (2007) Utility of coal petrology for sequence-stratigraphic analysis. Int J Coal Geol 70:3-34. https://doi.org/10. 1016/j.coal.2006.01.008

Dueñas Jiménez H, Hammen T (2007) Significado geológico y asociaciones palinológicas de las formaciones Diablo Inferior (Mioceno Tardío) y San Fernando Superior (Mioceno Medio), Piedemonte cuenca de los Llanos Orientales, Colombia. Rev la Acad Colomb ciencias exactas, físicas y Nat 31:481-498

Farhaduzzaman Md, Hasiah W, Islam A (2012) International journal of coal geology depositional environment and hydrocarbon source potential of the Permian Gondwana coals from the Barapukuria Basin, Northwest Bangladesh. Int J Coal Geol 90-91:162-179. https://doi.org/10.1016/j.coal.2011.12.006

Feng S, He J, Tian J et al (2019) The characteristic and evolution of coal-forming swamp in Hanshuiquan district, Santanghu Coalfield, Xinjiang, NW China, during the Middle Jurassic: evidence from coal petrography, coal facies and sporopollen. Int J Coal Sci Technol 6:1-14. https://doi.org/10.1007/s40789-018-0230-5

Finkelman RB, Dai S, French D (2019) The importance of minerals in coal as the hosts of chemical elements: a review. Int J Coal Geol 212:103251. https://doi.org/10.1016/j.coal.2019.103251

Gómez J, López M (2017) Paleoenvironments of Coals Using Organic Petrography and Their Relationship With physicochemical properties. Thesis, Universidad Pedagógica y Tecnológica de Colombia, Guaduas Formation Checua-Lenguazaque Syncline

Guatame C, Sarmiento Perez G (2004) Interpretación del Ambiente Sedimentario de los Carbones de la Formación Guaduas en el Sinclinal Checua-Lenguazaque a partir del análisis petrográfico. Geología Colombiana 29:41-58

Guerrero J, Sarmiento G (1996) Estratigrafía Física Palinológica Sedimentológica y Secuencial del Cretácico Superior y Paleoceno del Piedemonte Llanero. Implicaciones en Exploración Petrolera Geología Colombiana 20:3-66

Guo Q, Littke R, Zieger L (2018) Petrographical and geochemical characterization of sub-bituminous coals from mines in the Cesar-Ranchería Basin, Colombia. Int J Coal Geol 191:66-79. https://doi.org/10.1016/j.coal.2018.03.008

Horton BK, Parra M, Mora A (2020) Construction of the Eastern Cordillera of Co- lombia: Insights from the sedimentary record. In: Gómez J, Mateus-Zabala, D (eds) The Geology of Colombia, Vol 3 Paleogene - Neogene. Servicio Geológico Colombiano, Publicaciones Geológicas Especiales 37, pp. 22. Bogotá. https:// doi.org/10.32685/pub.esp.37.2019.03

Hou H, Shao L, Wang S et al (2019) Influence of depositional environment on coalbed methane accumulation in the Carboniferous-Permian coal of the Qinshui Basin, northern China. Front Earth Sci 13:535-550. https://doi.org/10.1007/s11707-018-07428

Hower JC, Ruppert LF (2011) Splint coals of the central appalachians: petrographic and geochemical facies of the Peach Orchard No. 3 splint coal bed south Magoffin County Kentucky. Int J
Coal Geol 85:268-275. https://doi.org/10.1016/j.coal.2010.12. 012

Hower JC, Eble CF, Dai S, Belkin HE (2016) Distribution of rare earth elements in eastern Kentucky coals: Indicators of multiple modes of enrichment? Int J Coal Geol 160-161:73-81. https:// doi.org/10.1016/j.coal.2016.04.009

Ingeominas, (2004) El carbón colombiano. Recursos reservas y calidad, Ingeominas, Bogotá

ICCP (1963) International Handbook of Coal Petrography, 2nd edn. CNRS, Academy of Sciences of the USSR, Paris Moscow

ICCP (1971) International handbook of coal petrography 1st supplement to, 2nd edn. CNRS, Paris

ICCP (1998) The new vitrinite classification (ICCP System 1994). Fuel 77:349-358

ICCP (2001) The new inertinite classification (ICCP System 1994). Fuel 80:459-471

ISO 7404-4 (1988) Petrographic analysis of bituminous coal and anthracite. Method of determining microlithotype carbominerite and minerite composition

ISO 11760 (2005) Classification of coals 1st ed. International Organization for Standardization Geneva Switzerland

ISO 7404-3 (2009) Methods for the petrographic analysis of coalspart 3: method of determining maceral group composition. International Organization for Standardization Geneva Switzerland

Jaramillo CA, Rueda M, Torres V (2011) A palynological zonation for the Cenozoic of the Llanos and Llanos Foothills of Colombia. Palynology 35:46-84. https://doi.org/10.1080/01916122.2010. 515069

Laxminarayana C, Crosdale PJ (1999) Role of coal type and rank on methane sorption characteristics of Bowen Basin, Australia coals. Int J Coal Geol 40:309-325. https://doi.org/10.1016/ S0166-5162(99)00005-1

Li S, Tang D, Pan Z, Xu H (2014) Influence and control of coal facies on physical properties of the coal reservoirs in Western Guizhou and Eastern Yunnan, China. Int J Oil, Gas Coal Technol 8:221-234. https://doi.org/10.1504/IJOGCT.2014.064837

Li X, Fu X, Liu A et al (2016) Methane adsorption characteristics and adsorbed gas content of low-rank coal in China. Energy Fuels 30:3840-3848. https://doi.org/10.1021/acs.energyfuels.6b00071

Mejía LJ, Convers CE, González JF (2006) Coal microlithotype analysis of the Guaduas Formation in the Sueva Syncline, Cundinamarca, Colombia. Geología Colombiana 31:11-26

Monroy W, Sandoval M (2016) Exploración y Evaluación de carbones en el área Sabanalarga Recetor del Departamento de Casanare. Servicio Geológico Colombiano

Monroy W, Sandoval M (2017) Exploración y Evaluación de carbones en el área Paratebueno Páez departamentos de Cundinamarca Casanare. Servicio Geológico Colombiano

Monroy W, Patiño R (2018) Exploración y evaluación de carbones en el área Serranía de las Palomas Mesetas Departamentos de Boyacá Cundinamarca y Meta. Servicio Geológico Colombiano

Moore TA, Shearer JC (2003) Peat/coal type and depositional environment - Are they related? Int J Coal Geol 56:233-252. https://doi.org/10.1016/S0166-5162(03)00114-9

Mukhopadhyay PK (1986) Petrography of selected Wilcox and Jockson Group lignites from Tertiary of Texas. In: Finkelman RB Casagrande DJ (eds) Geology of gulf coast lignites. Annual Meeting in Geol Soc Am, Field Trip of Coal Geology Division, pp. 126-145

Pardo A (2004) Paleocene-eocene palynology and palynofacies from northeastern Colombia and western Venezuela. Ph. D. Thesis Universite de Liege

Pardo A, Jaramillo C (2014) Palinology and paleoenvironments of Eastern Cordillera Paleogene deposits of Colombia: 35 million years of Neotropical vegetation history. In: Rangel O (ed) 
Colombia diversidad biótica XIV: Palinología y paleoambientes, 1st edn. Universidad Nacional, Bogotá, pp 1-30

Parra M, Mora A, Jaramillo C et al (2009) Orogenic wedge advance in the northern Andes: evidence from the oligocene-miocene sedimentary record of the medina basin, Eastern Cordillera, Colombia. Bull Geol Soc Am 121:780-800. https://doi.org/10. 1130/B26257.1Qu

Pickel W, Kus J, Flores D et al (2017) Classification of liptinite ICCP System 1994. Int J Coal Geol 169:40-61. https://doi.org/ 10.1016/j.coal.2016.11.004

Qiu N, Jiang G, Mei Q, Chang J, Wang S, Wang J (2011) The Paleozoic tectonothermal evolution of the Bachu Uplift of the Tarim Basin, NW China: constraints from (U-Th)/He ages, apatite fission track and vitrinite reflectance data. J Asian Earth Sci 41:551-563. https://doi.org/10.1016/j.jseaes.2011.02.008

Rimmer S, Hower J, Moore T, Esterle J, Walton R, Helfrich Ch (2000) Petrography and palynology of the blue gem coal bed. Middle Pennsylvanian southeastern Kentucky US. Int J Coal Geol 42:159-184. https://doi.org/10.1016/S01665162(99)00038-5

Sahay VK (2011) Limitations of petrographic indices in depositional environmental interpretation of coal deposits. Cent Eur J Geosci 3:287-290. https://doi.org/10.2478/s13533-011-0024-4

Sarmiento G (1992) Estratigrafía y medios de depósito de la Formación Guaduas. Boletín Geológico- Ingeominas $32(1-3): 1-44$

Scott AC (2002) Coal petrology and the origin of coal macerals: A way ahead? Int J Coal Geol 50:119-134. https://doi.org/10.1016/ S0166-5162(02)00116-7

Sen S, Naskar S, Das S (2016) Discussion on the concepts in paleoenvironmental reconstruction from coal macerals and petrographic indices. Mar Pet Geol 73:371-391. https://doi.org/ 10.1016/j.marpetgeo.2016.03.015

Seredin VV, Dai S (2012) Coal deposits as potential alternative sources for lanthanides and yttrium. Int J Coal Geol 94:67-93. https://doi.org/10.1016/j.coal.2011.11.001

Singh MP, Singh PK (1996) Petrographic characterization and evolution of the Permian coal deposits of the Rajmahal Basin Bihar India. Int J Coal Geol 29:3-118. https://doi.org/10.1016/ 0166-5162(95)00005-4

Singh MP, Singh AK (2000) Petrographic characteristics and depositional conditions of Eocene coals of platform basins, Meghalaya, India. Int J Coal Geol 42:315-356. https://doi.org/ 10.1016/S0166-5162(99)00045-2

Singh A, Singh M, Singh P (2013) Petrological investigations of oligocene coals from foreland basin of northeast India. Energy Explor Exploit 31:909-936. https://doi.org/10.1260/0144-5987. 31.6.909

Singh AK (2016) Petrographic characterization and evolution of the Karharbari coals, Talcher Coalfield, Orissa, India. Int J Coal Sci Technol 3:133-147. https://doi.org/10.1007/s40789-016-0132-3
Smyth M (1979) Hidrocarbon generation in the fly lake-brolga area of the cooper basin. J Aust Petro Explor Ass Sediment 19:108-114. https://doi.org/10.1071/AJ78012

Smyth M (1984) Coal microlithotypes to sedimentary environments in the cooper basin Australia. Spec Publics int Ass Sediment 7:333-347. https://doi.org/10.1002/9781444303797.CH19

Staub JR (2002) Marine flooding events and coal bed sequence architecture in southern West Virginia. Int $\mathrm{J}$ Coal Geol 49:123-145. https://doi.org/10.1016/S0166-5162(01)00074-X

Suárez Ruiz I, Crelling J (2008) Applied coal petrology. The role of petrology in coal utilization. Elsevier/Academic Press, Amsterdam

Suárez-Ruiz I, Flores D, Mendonça Filho JG, Hackley PC (2012) Review and update of the applications of organic petrology: part 1, geological applications. Int J Coal Geol 99:54-112. https:// doi.org/10.1016/j.coal.2012.02.004

Taylor GH, Teichmüller M, Davis A, Diessel CFK, Littke R, Robert P (1998) Organic Petrology. Gebrüder Borntraeger, Stuttgart

Teichmüller M, Teichmüller R (1982) Fundamentals of coal petrology. In: Teichmuller M, Taylor GH, Chandra D, Teichmuller R (eds) Stach E, Mackowsky, M-Th. Stach's Textbook of Coal Petrology, Gebruder Borntraeger, Berlin-Stuttgart, pp 5-219

Terraza R, Montoya D, Reyes G, Moreno G, Fúquen J, Torres E, López M, Nivia A (2013) Geología de la plancha 229 Gachalá. Servicio Geológico Colombiano

Tissot BP, Welte DH (1978) Petroleum formation and occurrence. A new approach to oil and gas exploration. 1st ed. BerlinHeidelberg. https://doi.org/10.1007/978-3-642-96446-6

Ulloa C, Rodríguez E (1976a) Mapa Geológico de la Plancha 211-Tauramena. Escala 1: 100.000. Ingeominas, Bogotá

Ulloa C, Rodríguez E (1976) Geología del Cuadrángulo K12Guateque. Ingeominas, Bogotá

Van Krevelen DW (1961) Coal: Typology- Chemistry- PhysicsConstitution, 1st edn. Elsevier, Amsterdam

Van Krevelen DW (1993) Coal: Typology- Chemistry- PhysicsConstitution, 3rd edn. Elsevier, The Netherlands

Villamil T (1999) Campanian-Miocene tectonostratigraphy, depocenter evolution and basin development of Colombia and western Venezuela. Palaeogeogr Palaeoclimatol Palaeoecol 153:239-275. https://doi.org/10.1016/S0031-0182(99)00075-9

Wüst RAJ, Hawke MI, Bustin RM (2001) Comparing maceral ratios from tropical peatlands with assumptions from coal studies: do classic coal petrographic interpretation methods have to be discarded? Int J Coal Geol 48:115-132. https://doi.org/10.1016/ S0166-5162(01)00050-7

Zhao J, Qin Y, Shen J et al (2019) Effects of pore structures of different maceral compositions on methane adsorption and diffusion in anthracite. Appl Sci. https://doi.org/10.3390/ app9235130 